\title{
Gephyrin, the enigmatic organizer at GABAergic synapses
}

\author{
Verena Tretter ${ }^{1}$, Jayanta Mukherjee ${ }^{2}$, Hans-Michael Maric ${ }^{3}$, Hermann Schindelin ${ }^{3}$, Werner Sieghart $^{1}$ \\ and Stephen J. Moss ${ }^{2}$ \\ 1 Department of Biochemistry and Molecular Biology, Center for Brain Research, Medical University Vienna, Vienna, Austria \\ 2 School of Medicine, Tufts University, Boston, MA, USA \\ ${ }^{3}$ Rudolf Virchow Center for Experimental Biomedicine, University of Würzburg, Würzburg, Germany
}

Edited by:

Enrico Cherubini, International

School for Advanced Studies, Italy

Reviewed by:

Antoine Triller, Ecole normale

supérieure, France

Theofilos Papadopoulos, Max-Planck Institute of Experimental Medicine,

Germany

\section{*Correspondence:}

Verena Tretter, Department of

Biochemistry and Molecular Biology,

Center for Brain Research, Medical

University Vienna, Spitalgasse 4,

1090 Vienna, Austria.

e-mail:eva.tretter@

meduniwien.ac.at
$\mathrm{GABA}_{A}$ receptors are clustered at synaptic sites to achieve a high density of postsynaptic receptors opposite the input axonal terminals. This allows for an efficient propagation of GABA mediated signals, which mostly result in neuronal inhibition. A key organizer for inhibitory synaptic receptors is the $93 \mathrm{kDa}$ protein gephyrin that forms oligomeric superstructures beneath the synaptic area. Gephyrin has long been known to be directly associated with glycine receptor $\beta$ subunits that mediate synaptic inhibition in the spinal cord. Recently, synaptic $\mathrm{GABA}_{A}$ receptors have also been shown to directly interact with gephyrin and interaction sites have been identified and mapped within the intracellular loops of the $\mathrm{GABA}_{A}$ receptor $\alpha 1, \alpha 2$, and $\alpha 3$ subunits. Gephyrin-binding to $\mathrm{GABA}_{A}$ receptors seems to be at least one order of magnitude weaker than to glycine receptors (GlyRs) and most probably is regulated by phosphorylation. Gephyrin not only has a structural function at synaptic sites, but also plays a crucial role in synaptic dynamics and is a platform for multiple protein-protein interactions, bringing receptors, cytoskeletal proteins and downstream signaling proteins into close spatial proximity.

\section{INTRODUCTION}

The impressive performance of the central nervous system is rendered possible by neuronal networks that form an uncountable number of flexible synaptic contacts passing on information from one cell to many others. Information processing is primarily achieved by fast acting signals, i.e., neurotransmitters acting on synaptic ligand-gated ion channels and slower mechanisms like extrasynaptic receptors and G-protein coupled receptors (GPCRs). The main counter-acting neurotransmitters, glutamate and GABA ( $\gamma$-amino butyric acid), both exert their actions through ligand-gated ion channels and GPCRs. Synapses are highly complex structures, where a large number of proteins control neurotransmitter release on the presynaptic site and the effects of neurotransmitters at the postsynaptic site.

The glutamatergic synapse has been investigated in great detail over the past 20 years and these studies have revealed a large number of postsynaptic proteins that interact in a controlled manner to keep glutamate receptors in place but also allow for a highly regulated dynamic insertion and removal of receptors, which is a prerequisite for synaptic plasticity. Sub-membrane adaptor and scaffold proteins are crucial players in this process. The intracellular C-termini of glutamate receptors (Figure 1A) strongly interact with modular intracellular scaffold and signaling proteins (like PSD-95) via well-characterized protein-protein interaction motifs (like PDZ, SH3, and other domains). It was, therefore, experimentally easier to find intracellular interaction partners using the classical yeast-two-hybrid system and to finally assemble the concept of the complex dynamic structure of the excitatory postsynaptic density as we understand it today (Sheng and Lin, 2001).
The postsynaptic structure of inhibitory synapses turned out to be more difficult to investigate. In $\mathrm{GABA}_{\mathrm{A}}$ receptors $\left(\mathrm{GABA}_{\mathrm{A}} \mathrm{Rs}\right)$, which belong to the Cys-loop receptor family, the $\mathrm{N}$ - and C-termini are both extracellular and possible intracellular interactions can only be mediated by a small intracellular loop between transmembrane helices (TM) 1 and 2, or the large intracellular loop between TM3 and 4 of individual subunits. (Figure 1A). A further difficulty is the complexity of the $G_{A B A_{A}} R$ composition. There are a total of 19 subunits from eight subunit classes $(\alpha, \beta, \gamma, \delta, \varepsilon, \pi, \rho, \theta)$ that come together in pentameric assemblies with different compositions and form a central pore that is permeable to chloride ions (Figure 1B) (Sarto-Jackson and Sieghart, 2008). Depending on cell type, the individual synapses and the developmental state, the subunit composition of the pentameric receptor is predominantly recruited from six different $\alpha$ subunits, $3 \beta$ subunits, and $3 \gamma$ subunits (some of which also occur in alternatively spliced forms). These subunit categories were defined by the degree of their sequence similarity with $30-40 \%$ sequence identity between members of different subunit classes and 60-80\% identity between members of the same subunit class (Barnard et al., 1998). Interestingly, the highest variability between members within a class and between classes is found in the large intracellular loop between TM3 and 4 (Olsen and Sieghart, 2008).

The most common synaptic receptors are formed by $\alpha_{1 / 2 / 3 / 6}-\beta_{x}-\gamma_{2}$ subunit combinations. They respond to the shortlived bursts $(<1 \mathrm{~ms})$ of high concentrations of GABA (mM range) during neurotransmitter release into the synaptic cleft with receptor kinetics characterized by a fast rise time, high amplitude, and fast inactivation. Receptors composed of $\alpha \beta$ or $\alpha_{4 / 6} \beta \delta$ subunits 


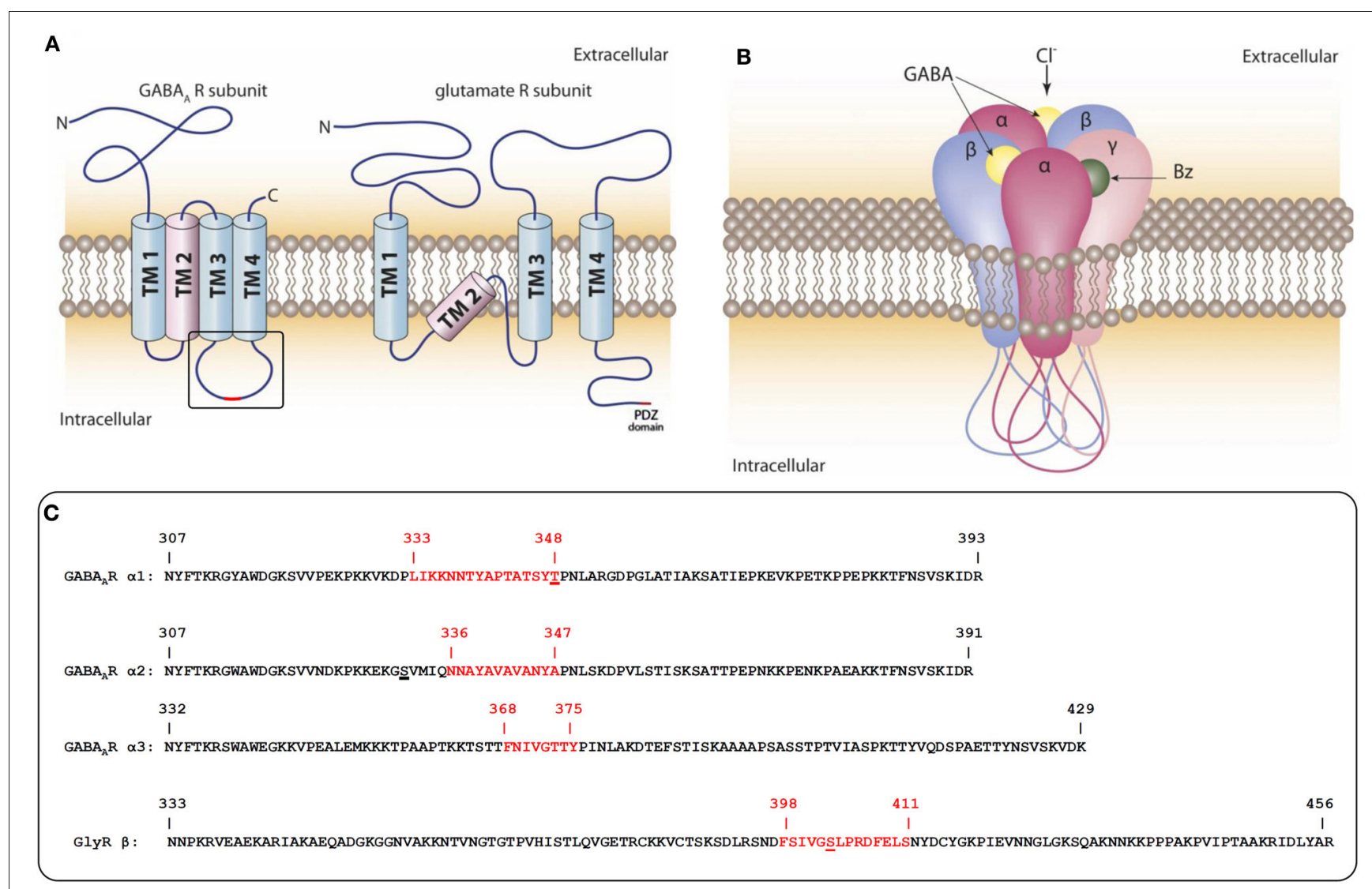

FIGURE 1 | Domain-structure of $\mathrm{GABA}_{A}$ R- and GluR-subunits and the pentameric assembly of $\mathrm{GABA}_{\mathbf{A}}$ Rs. (A) Schematic representation of the transmembrane topology of subunits from GABA $R$ and AMPA/NMDA (glutamate) receptors. The $\mathrm{GABA}_{A} \mathrm{R}$ intracellular loop between TM3 and 4 and the intracellular C-terminus of glutamate receptors are the main sites of interaction with intracellular scaffold and signaling proteins. (B) Pentameric assembly of subunits within the $G_{A B A} R$ : subunit interfaces of the extracellular domains form binding pockets for many therapeutically used drugs. The intracellular loops of all five subunits are substrates for post-translational modifications that dynamically regulate interactions with other proteins. Some protein interactions might require more than one cytoplasmic loop. (C) Sequences of intracellular loops of GABAA $R \alpha 1, \alpha 2$, and $\alpha 3$ subunits and the GlyR $\beta$ subunit from rat. The sequences identified as gephyrin interaction sites are highlighted in red. Identified phosphorylation sites within or near the gephyrin interaction sites are underlined. are believed to form a specialized population of extrasynaptic receptors. They have a higher agonist affinity and longer open times than their synaptic counterparts and respond to lower ambient GABA concentrations ( $\mu \mathrm{M}$ range) or to GABA spillover from synapses and provide the respective neuron with a constant tonic inhibition that elevates the threshold of action potential firing (Farrant and Nusser, 2005). Those receptors are either distributed in a dispersed manner on the cell surface or form micro-clusters with intracellular scaffold proteins that are different from those of synaptic receptors. Of particular pharmacological relevance is the sensitivity of the large number of $\mathrm{GABA}_{\mathrm{A}} \mathrm{R}$ subtypes toward allosteric modulators such as benzodiazepines and neurosteroids (Rudolph and Mohler, 2004).

To search for downstream effectors that are involved in the construction of the inhibitory synapse it is important to keep in mind that there are five large intracellular loops per single receptor complex as potential interaction sites with intracellular molecules (Figures 1A,B). These loops also contain multiple sites for post-translational modifications (like phosphorylation, palmitoylation, sumoylation, and ubiquitylation). These modifications dynamically regulate the interactions with other proteins and are involved in synaptic stability and trafficking (Moss and Smart, 2001).

Similar to glutamate receptors yeast-two-hybrid screens were used intensively to identify intracellular interaction partners of $\mathrm{GABA}_{\mathrm{A}} \mathrm{R}$ subunits, but turned out to be more laborious than with glutamate receptors. The first proteins to be identified by this technique were proteins involved in the assembly (chaperones) and trafficking (like MAP-1B, PLIC, GABARAP) (Hanley et al., 1999; Wang et al., 1999; Bedford et al., 2001). Kinases and phosphatases were also among the first proteins to be shown to interact with $\mathrm{GABA}_{\mathrm{A}}$ Rs (Brandon et al., 2002, 2003). These enzymes usually bind to their substrate upon phosphorylation or de-phosphorylation either directly or via an adaptor protein like AKAP-79/150 for protein kinase A (PKA). GABA $\mathrm{R}$ interacting proteins have been extensively reviewed in Jacob et al. (2008); Tretter and Moss (2008) and Luscher et al. (2011). 


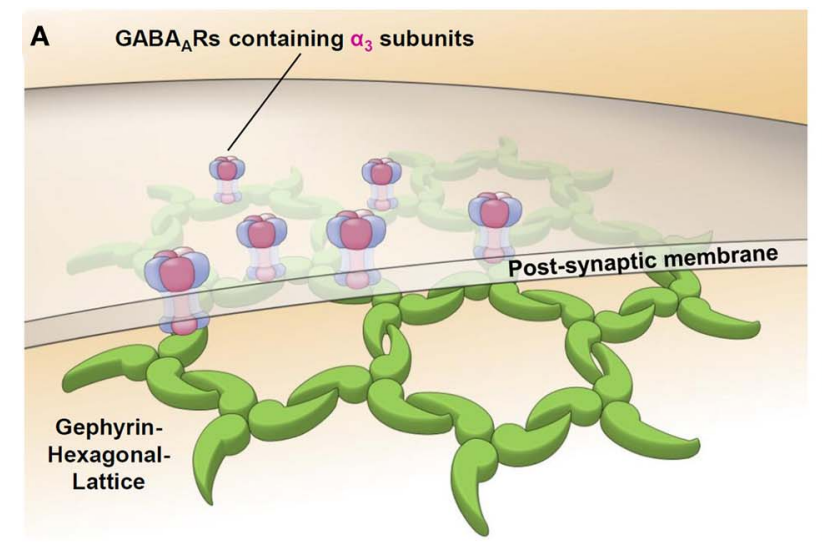

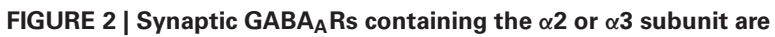
clustered by different mechanisms. Schematic representations of GABAergic post-synapses containing the $G_{A B A_{A}} R \alpha 3$ subunit $(\mathbf{A})$ or the $G_{A B A_{A}} R \alpha 2$ subunit (B) show the postulated differential role of collybistin in synaptic cluster formation. GABA $\mathrm{A}_{A}$ s containing the $\alpha 3$ subunit directly

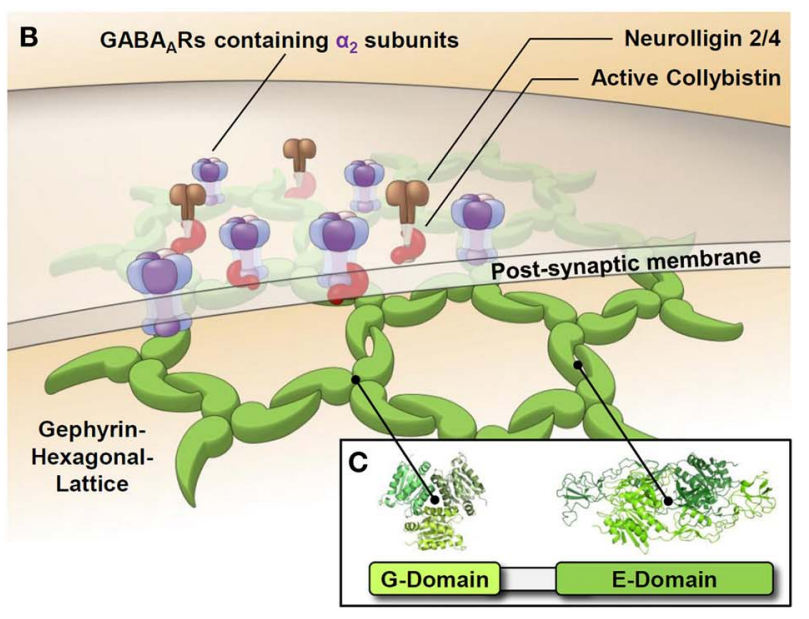

bind to gephyrin, while $\mathrm{GABA}_{\mathrm{A}}$ Rs containing the $\alpha 2$ subunit use collybistin as an accessory factor to enhance the affinity of binding to gephyrin. Isoforms of the cell adhesion molecule neuroligin (NL-2/4) have a preference for GABAergic synapses and have been shown to activate collybistin.
One particular protein, gephyrin, soon gained a lot of scientific attention as a $\mathrm{GABA}_{\mathrm{A}} \mathrm{R}$ associated protein. It was originally identified to interact with GlyRs that mediate inhibition in the spinal cord and are also members of the Cys-loop receptor family. During receptor purification, GlyRs remain strongly associated with this prominent intracellular anchoring protein, which has been named gephyrin after the Greek word for "bridge" gephyra (Langosch et al., 1992; Prior et al., 1992). The observation that $\mathrm{GABA}_{\mathrm{A}}$ Rs also colocalize to a large degree with gephyrin in the brain was made soon after this protein was identified, but it was neither possible to co-precipitate or co-purify gephyrin with $\mathrm{GABA}_{\mathrm{A}} \mathrm{R}$ nor was it found in yeast-two-hybrid screens using many kinds of brain mRNA libraries and $G_{A B A} R$ intracellular loops as baits (Sassoè-Pognetto et al., 1995; Betz, 1998; Essrich et al., 1998). It only turned out recently that, similar to GlyRs, there is indeed a direct interaction between $\mathrm{GABA}_{\mathrm{A}} \mathrm{Rs}$ and gephyrin, but a co-purification using classical protocols has not been reported.

\section{GABA $_{A}$ RECEPTOR INTERACTIONS WITH GEPHYRIN}

Gephyrin clusters are very abundant in the brain, where GlyRs are a minor receptor population compared to $\mathrm{GABA}_{\mathrm{A}} \mathrm{Rs}$. The colocalization of $\mathrm{GABA}_{\mathrm{A}}$ Rs and gephyrin in clusters on the neuronal surface implied that $\mathrm{GABA}_{\mathrm{A}}$ Rs are associated with this scaffold protein, either directly or indirectly (via a linker protein). The $\mathrm{GABA}_{\mathrm{A}} \mathrm{R} \gamma 2$ subunit was originally found to be important for synaptic localization of $\mathrm{GABA}_{\mathrm{A}}$ Rs (Essrich et al., 1998). Knockout mice with a deletion of the $\gamma 2$ subunit die within a few weeks after birth and were found to lack $\mathrm{GABA}_{\mathrm{A}} \mathrm{R}$ clusters (Günther et al., 1995). Transfection of neuronal cultures from these mice with $\gamma 2$ cDNA restored clustering (Baer et al., 2000). On the other hand, transfecting cultured hippocampal neurons with shRNAi constructs against gephyrin reduces the number of $\gamma 2$ containing $\mathrm{GABA}_{\mathrm{A}} \mathrm{R}$ clusters in cultured hippocampal neurons (Yu et al.,
2007). Similarly, cultures from gephyrin knock-out mice lack $\mathrm{GABA}_{\mathrm{A}} \mathrm{R}$ clusters (Kneussel et al., 1999).

One of the early hits from yeast-two-hybrid screens, the protein GABARAP (GABA $\mathrm{R}$ associated protein), was identified to interact with the $\gamma 2$ subunit as well as with gephyrin (Wang et al., 1999; Kneussel et al., 2000). This finding led to the hypothesis, that GABARAP might be the linker protein that connects $\mathrm{GABA}_{\mathrm{A}}$ Rs to gephyrin clusters. As a consequence GABARAP was intensively investigated and found to be important for receptor insertion into the cell surface membrane (Kittler et al., 2001; Bavro et al., 2002). GABARAP is widely distributed in multiple cell types and its relatively low abundance at synaptic sites raised doubts about its role as a linker protein. Finally, GABARAP knock-out mice turned out to be viable and neuronal cultures from these mice exhibited strong postsynaptic co-clustering of gephyrin and $\mathrm{GABA}_{\mathrm{A}}$ Rs (O'Sullivan et al., 2005). Soon, the discovery of other GABARAP-interacting proteins, PRIP1/2 (Phospholipase C-Related Inactive Protein) and NSF (N-ethylmaleimide Sensitive Fusionprotein) supported its function during synaptic delivery of receptors (Kittler et al., 2001; Goto et al., 2005; Kanematsu et al., 2006). This task probably is taken over by other members of the MAP1-LC3 family in GABARAP knock-out mice.

The $\gamma 2$ subunit has long been discussed as an important candidate for mediating synaptic targeting or anchoring (Alldred et al., 2005; Christie et al., 2006). This concept was obvious as $\gamma 2$ and $\delta$ do not occur together in one receptor subtype and follow distinct assembly rules (Sieghart et al., 1999). As mentioned earlier, $\delta$ subunit containing receptors are well described as being localized mostly outside of the synaptic areas where they mediate tonic inhibition (Farrant and Nusser, 2005). The currently accepted model of receptor structure predicts the presence of $2 \alpha, 2 \beta$, and $1 \gamma$ subunit in the pentameric ion channel (Barrera and Edwardson, 2008). The $\gamma 2$ subunit is known to 
exist in two splice variants $(\gamma 2 \mathrm{~L}$ and $\gamma 2 \mathrm{~S}$, distinguished by the insertion of eight amino acids in the TM3-4 intracellular loop of $\gamma 2 \mathrm{~L}$ containing a PKC phosphorylation site). This might be of some importance in the regulation of receptor trafficking and synaptic targeting (Meier and Grantyn, 2004). Staining of hippocampal pyramidal neurons in culture reveals a strong diffuse cell surface distribution of $\gamma 2$ in addition to synaptic clusters, while staining for $\alpha 2$ reveals predominantly synaptic clusters and staining for $\alpha 1$ reveals both: synaptic clusters and smaller clusters or diffuse staining in extrasynaptic areas (Tretter and Moss unpublished results). Therefore, many $\gamma 2$ containing receptors are extrasynaptic. This is not only true for hippocampal cell cultures but also for $\mathrm{GABA}_{\mathrm{A}}$ receptor in the brain (Kasugai et al., 2010).

Hippocampal pyramidal cells express a large repertoire of $\mathrm{GABA}_{\mathrm{A}} \mathrm{R}$ subtypes containing the $\gamma 2$ but different $\alpha$ and $\beta$ subunits in different synapses (Klausberger et al., 2002). Although synaptic targeting and anchoring must be distinguished as two different processes, $\alpha$ subunits are more likely to dominate over the $\gamma 2$ subunit in at least one of these processes. Furthermore the $\gamma 2$-containing GABA $\mathrm{R}$ subtype $\alpha_{5} \beta_{x} \gamma_{2}$, that has received considerable attention in context with a role in cognition has been found to be located mostly at extrasynaptic sites where it was found to be associated with the sub-membrane protein radixin (Kneussel, 2005; Loebrich et al., 2006; Serwanski et al., 2006). Therefore, it was assumed that $\gamma 2$ subunits might not be involved in synaptic targeting, but possibly in the synaptic anchoring of $\mathrm{GABA}_{\mathrm{A}} \mathrm{R}$.

Finally, in 2008 a direct interaction between some $\mathrm{GABA}_{\mathrm{A}} \mathrm{R}$ $\alpha$ subunits and the P1 splice variant of gephyrin could be successfully proven (Tretter et al., 2008). We found that some $\mathrm{GABA}_{\mathrm{A}} \mathrm{R}$ mutants were expressed on neuronal surfaces, but were clustering-deficient. An overlay assay protocol was adapted to specific conditions: following a Western blot, the GST fusion proteins of $\mathrm{GABA}_{\mathrm{A}} \mathrm{R}$ intracellular domains were slowly renatured with a decreasing gradient of guanidinium hydrochloride and were incubated with in vitro translated gephyrin in the absence of detergent. This was a prerequisite for a positive and specific signal. The expectation that the large intracellular loop between TM3 and 4 contains the interaction site with gephyrin was thus verified. The first $\alpha$ subunit to be shown to interact with gephyrin was $\alpha 2$. The identified minimal core-sequence that is necessary for receptor clustering comprises amino acids 336-347 (Figure 1C), or amino acids 364-375, when numbering includes the signal sequence. In order to obtain a positive signal in yeast-two-hybrid screens an extended sequence of amino acids, 330-347 (358-375 including the signal sequence) was necessary (Saiepour et al., 2010). The motif is a highly hydrophobic stretch of amino acid residues in the center of the large intracellular loop. Subsequently, we also identified gephyrin interaction motifs in the homologous region of $\alpha 1$ and a3 (Mukherjee et al., 2011; Tretter et al., 2011). Interestingly these $\alpha$ subunits show little conservation of the amino acid sequence in this area (Figure 1C), which either implies different binding sites on gephyrin, or suggests an important role of a higher order structure that is conserved among these subunits.

\section{BINDING SITE OF GABA A RECEPTOR $\alpha$ SUBUNITS ON GEPHYRIN}

The binding site of the GlyR $\beta$ subunit (GlyR $\beta$ ) on gephyrin was initially identified as a stretch of residues at the beginning of gephyrin's C-terminal E-domain (GephE, for domain structure see Figure 3C). In 2006, the GlyR $\beta$-loop was co-crystallized with the E-domain of gephyrin, showing that amino acids at the beginning and the end of the E-domain seem to be involved in GlyR $\beta$ subunit binding (Schrader et al., 2004; Kim et al., 2006). Based on the structure of the GlyR $\beta$ subunit-gephyrin complex and sequence similarities in the $\mathrm{GABA}_{\mathrm{A}} \mathrm{R} \alpha 3$ subunit we hypothesized, that binding of $\alpha 3$ to gephyrin very likely occurs in a similar three-dimensional binding pocket of the gephyrin Edomain. As a crystal structure is currently not available, we first roughly mapped the binding sites of $\mathrm{GABA}_{\mathrm{A}} \mathrm{R} \alpha 2$ and $\alpha 3$ subunits on gephyrin by using alanine mutagenesis in a yeast two-hybrid system (Saiepour et al., 2010; Tretter et al., 2011). The identified sequences for $\alpha 2$ (residues 325-343) and $\alpha 3$ (residues 325-334) overlap and include the critical aminoacids involved in GlyR $\beta$ subunit binding (Asp327, Phe330) (Figure 3C). These results imply an evolutionarily conserved binding site for $\mathrm{GABA}_{\mathrm{A}} \mathrm{R} \alpha$ subunits and GlyR $\beta$ subunit on gephyrin.

The key residues for the interaction were further characterized in a follow-up study (Maric et al., 2011). Although the identified binding sites on $\alpha 1, \alpha 2$, and $\alpha 3$ are only moderately conserved, $\mathrm{GABA}_{\mathrm{A}} \mathrm{R} \alpha 1, \alpha 2, \alpha 3$, and GlyR $\beta$ subunits compete for the same binding site on the gephyrin molecule (Maric et al., 2011; and Figure 3D). Phe330 and Asp327 of GephE are the main critical residues mediating the GlyR $\beta$-gephyrin interaction (Kim et al., 2006). The crystal structure of the gephyrin E-domain itself and in complex with a bound GlyR $\beta$ peptide reveals the formation of Geph-E dimers (indicated by the grey structure in Figure 3A), but the main interaction site seems to be located on one molecule (indicated by the colored structure in Figure 3A) (Kim et al., 2006). It can be predicted that Phe330 in the gephyrin E-domain also mediates hydrophobic interactions with conserved aromatic residues in the $\mathrm{GABA}_{\mathrm{A}} \mathrm{R}$ $\alpha$ subunits. The motif "FSIV" in GlyR $\beta$ (Figures 3B,D) fits into the three-dimensional binding pocket formed mainly by residues of the N-terminus of GephE (subdomain III in Figure 3C), but also a few residues near the C-terminus of GephE (subdomain IV in Figures 3B,C color-coded in light blue) (Kim et al., 2006). This sequence of GlyR $\beta$ is highly conserved in $G_{A B A_{A}} R$ $\alpha 3$ ("FNIV") (Figure 3D). Another interesting conserved amino acid is a tyrosine in each of the $\mathrm{GABA}_{\mathrm{A}} \mathrm{R} \alpha$ subunit interaction domains ( $\alpha 1 Y 347, \alpha 2$ Y346, $\alpha 3$ Y375) (Figure 3D). Mutation of the respective tyrosine to phenylalanine or alanine reduces gephyrin-binding significantly (Maric et al., 2011). A related phenylalanine (Gly $\beta$ F408) is also found in a similar position of the GlyR $\beta$ subunit, yet it is shifted by three residues toward the C-terminus (Figure 3D).

Isothermal titration calorimetry is a frequently used thermodynamic method to quantify the strength and nature of proteinprotein interactions. We used this method to additionally prove, that GlyR $\beta$ and $\mathrm{GABA}_{\mathrm{A}} \mathrm{R} \alpha 1, \alpha 2, \alpha 3$ binding sites compete for the same site on GephE. The interaction of gephyrin $\mathrm{E}$ domain or full-length gephyrin with GlyR $\beta$ residues $378-425$ of the large 


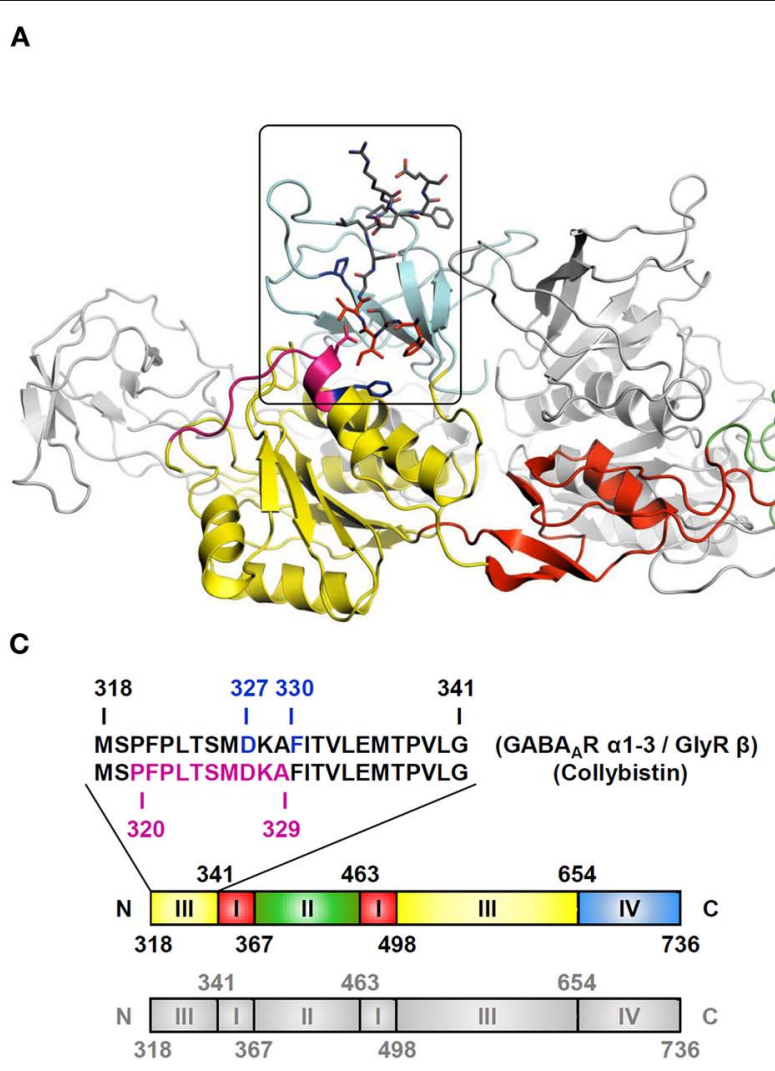

FIGURE 3 | Structural determinants of gephyrin, interacting with GABA $_{A}$ Rs, GlyRs, and collybistin. (A) Crystal structure of the gephyrin E domain (GephE) complexed with GlyR $\beta$, modified for comparison with $\mathrm{GABA}_{A} \mathrm{R} \alpha$ subunits and collybistin. The ribbon diagram of GephE is colored to highlight its subdomain architecture. The GephE-domain is complemented by a second monomer shown in grey, representing the dimer that usually forms in vitro. Identified binding sites for collybistin on gephyrin are shown in magenta and overlapping binding sites for GlyR $\beta$ and $G_{A B} A_{A} R \alpha$ subunits are shown in light blue. The GlyR $\beta$ peptide as well as crucial interacting amino acids in GephE (D327, F330, P713) are shown in stick representation. (B) The major contributing residues to the interaction are
B

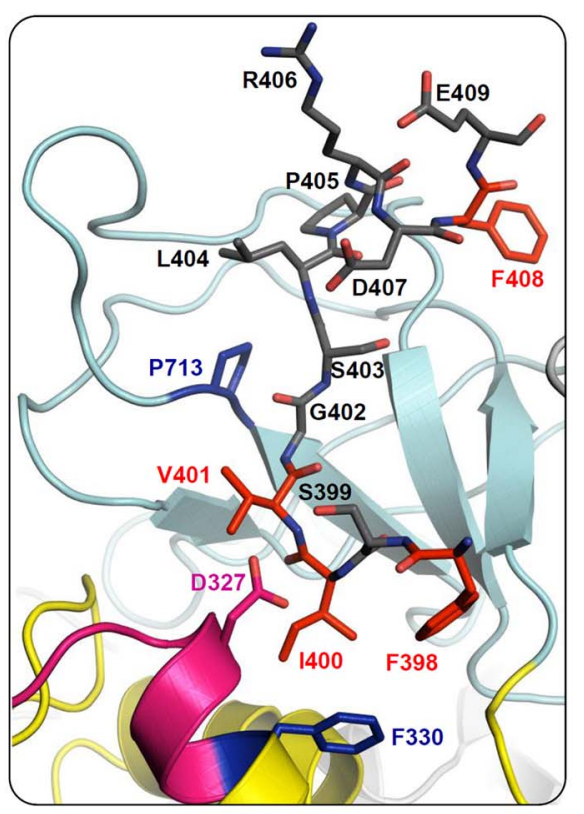

D conserved among GABA $R$ R $\alpha$ and GlyR $\beta$ and are marked in red. (C) Subdomain-structure of GephE and amino acid sequence of GephE harboring the main binding site to $\mathrm{GABA}_{A} R \alpha 1, \alpha 2$, and $\alpha 3$ subunits, GlyR $\beta$ subunit and collybistin. Crucial residues for the interaction with receptors are highlighted in light blue (Asp327, Phe330), the overlapping collybistin binding site is shown in magenta. (D) The table compares homologous sequences crucial for gephyrin-binding in GlyR $\beta$ and $G A B A_{A} R \alpha$ subunits from rat.

Residues critically contributing to the interaction and conserved among all subtypes are shown in red. The dissociation constant $K_{D}$ indicates the binding strength as determined by isothermal titration calorimetry. (n.d. = not detectable). cytoplasmic loop was analyzed intensively via ITC and based on the resulting biphasic binding curve a two-binding-sites model was used to describe the binding event. In particular, the high affinity binding site of the elongated GlyR $\beta$ was described to be in the nanomolar range with values varying between $22-30 \mathrm{nM}$ (Specht et al., 2011; Herweg and Schwarz, 2012) and 140-400 nM (Schrader et al., 2004; Kim et al., 2006) depending on the stoichiometry values which were estimated at 0.28-0.29 (Specht et al., 2011; Herweg and Schwarz, 2012) and 0.7-1.0 (Schrader et al., 2004; Kim et al., 2006), respectively. The low affinity site displayed affinities of 3-6 $\mu \mathrm{M}$ (Specht et al., 2011; Herweg and Schwarz, 2012) and 16-30 $\mu \mathrm{M}$ (Schrader et al., 2004; Kim et al., 2006) with a stoichiometry of 0.6 (Specht et al., 2011; Herweg and Schwarz, 2012) and 0.6-0.8 (Schrader et al., 2004; Kim et al., 2006). This deviation may be explained by lab-specific systematic differences in protein activity; depending on the purification protocol the discrepancy between active molecules and apparent concentration may vary. A low active fraction of macromolecules in the cell will yield overestimated affinities and underestimated stoichiometry values. In contrast, the discrepancy of a single binding site in the crystal structure versus two binding sites in ITC remains to be explained on the molecular level. Remarkably, both, alanine point mutations and phosphomimetic substitutions in the GlyR $\beta$ binding motif, result in monophasic binding curves describing a single binding site with low micromolar affinity (Kim et al., 2006; Specht et al., 2011). We propose that structural rearrangements in either the receptor loop or gephyrin may explain the second apparent binding site. Interestingly, measurements of the affinity of the $\mathrm{GABA}_{\mathrm{A}} \mathrm{R} \alpha$ subunits to gephyrin revealed monophasic binding curves with affinities in the low micromolar range for $\alpha 3: K_{D}=5.3 \mu \mathrm{M}$ and $\alpha 1: K_{D}=20 \mu \mathrm{M}$. The hydrophobic $\alpha 2$ peptide could not be synthesized in sufficiently high amounts to perform similar experiments (Maric et al., 2011). The affinities of the $\mathrm{GABA}_{\mathrm{A}} \mathrm{R} \alpha$ subunits to gephyrin are, therefore, one to two orders of magnitude weaker and are comparable to those of PDZ domain-ligand interactions such 
as PSD-95 with its binding partners at glutamatergic synapses (Jemth and Gianni, 2007). In vivo, the affinity may be influenced by various additional factors including the presence of full-length proteins, the contribution of other subunits in the pentamer, post-translational modifications and accessory proteins like collybistin (see below). GlyRs differ from $\mathrm{GABA}_{\mathrm{A}}$ Rs also in the stoichiometry and assembly of subunits. The higher affinity of gephyrin to one GlyR $\beta$ subunit and the presence of 2 or $3 \beta$ subunits in one GlyR pentamer is a plausible explanation for the co-purification of gephyrin with GlyRs from detergent extracts (Sola et al., 2004).

The $\alpha$ subunits seem to be the lead subunits in gephyrindependent $\mathrm{GABA}_{\mathrm{A}} \mathrm{R}$ clustering. Deletion of the gephyrin-binding motifs in tagged recombinant $\alpha$ subunits prevented recombinant receptors from co-clustering with endogenous gephyrin after transfection into cultured hippocampal neurons, but did not prevent assembly with endogenous $\beta$ and $\gamma$ subunits and surface expression of receptors. Vice versa, it has been shown, that the insertion of the $\alpha 2$-binding site into the intracellular region of $\alpha 6$, or even into unrelated proteins like $\mathrm{CD} 4$, redirects these proteins to gephyrin clusters (Tretter et al., 2008). The sequence of events, however, is still not fully understood. Several studies have investigated $\mathrm{GABA}_{\mathrm{A}} \mathrm{R}$ assembly. As membrane proteins, GABA $\mathrm{Rs}$ pass the ER/Golgi, where individual subunits are assembled into pentamers with the help of chaperones like calnexin and binding immunoglobulin protein (BIP) (Connolly et al., 1996). $\mathrm{N}$-terminal and some cytoplasmic sequences are essential for receptor assembly (Taylor et al., 1999, 2000; Klausberger et al., 2001, 2002; Sarto et al., 2002; Bollan et al., 2003; Ehya et al., 2003; Sarto-Jackson et al., 2006), however, it is still unknown, at which stage gephyrin associates with $\mathrm{GABA}_{\mathrm{A}} \mathrm{Rs}$.

Although gephyrin-binding sites have now been identified on $\mathrm{GABA}_{\mathrm{A}} \mathrm{R} \alpha$ subunits, there is considerable evidence, that other subunits are somehow involved in the interaction.

We assume that apart from the $\alpha$ subunits, $\gamma 2$ also plays an active part in the clustering process explaining the earlier results from $\gamma 2$ knock-out mice (Schweizer et al., 2003). However, the precise mechanism remains to be determined. Although speculative at this point, it is quite possible that an interface formed between the cytoplasmic loops of the $\alpha 1, \alpha 2$, or $\alpha 3$ subunits and the $\gamma 2$ subunit might be crucial for, or at least strengthen gephyrin-binding, while the $\alpha$ subunit provides the major binding site and probably also mediates synapse-specificity. This interface might be critical: receptors without a $\gamma 2$ or $\delta$ subunit not only appear as fully functional recombinant receptors at the surface of transfected heterologous cells, but have also been identified as an endogenous receptor population in neurons (Bencsits et al., 1999). In hippocampal neurons they are located extrasynaptically and contribute to tonic inhibition (Mortensen et al., 2010). Although the presence of such subunit combinations in synaptic areas is also possible, they probably are of minor quantitative importance and experimentally difficult to distinguish from $\gamma 2$-containing receptors, especially if they occur in the same synapse.

We cannot make any predictions for $\alpha_{4 / 6} \beta_{2 / 3} \delta$ containing receptors yet, as $\alpha 4$ and $\alpha 6$ subunits have not been investigated in detail regarding a possible interaction with gephyrin. However, $\delta$-containing receptors have long been considered to be responsible for providing significant tonic inhibition of neurons at extrasynaptic sites. These $\delta$-containing receptors are rarely seen clustered, and are mostly distributed evenly on the neuronal surface (Nusser et al., 1998). The stoichiometry of these receptors might be similar to the $\alpha-\beta-\gamma$ receptors, except that $\delta$ replaces the $\gamma$ subunit although some authors have observed a variable stoichiometry in recombinant $\delta$-containing receptors depending on the availability of the $\delta$ subunit (Kaur et al., 2009; Baur et al., 2010; Wagoner and Czajkowski, 2010).

\section{GEPHYRIN-INDEPENDENT GABA $A$ RECEPTOR CLUSTERING}

Immunohistochemical studies investigating the distribution of $\mathrm{GABA}_{\mathrm{A}} \mathrm{R}$ subunits and gephyrin in tissue sections from wildtype and mutant mice have indicated that $G_{A B A} R$ subunit clusters are not always associated with gephyrin. This gephyrinindependent $\mathrm{GABA}_{\mathrm{A}} \mathrm{R}$ clustering is not fully understood at present. One alternative and completely independent form of clustering has been described and characterized: Radixina protein from the band 4.1 or ERM (ezrin-radixin-moesin) family-has been shown to cluster $\alpha 5$-containing receptors at extrasynaptic sites (Funayama et al., 1991; Loebrich et al., 2006). These receptors have gained considerable attention in cognition and $\alpha 5$-selective inverse agonists are under investigation as cognition enhancers in neurodegenerative disorders like Alzheimer's disease (AD) (Martin et al., 2009). Radixin connects $\alpha 5$-containing $\mathrm{GABA}_{\mathrm{A}} \mathrm{Rs}$ to the actin cytoskeleton. The $\mathrm{N}$ - and $\mathrm{C}$-termini of radixin form intra-molecular associations that are disrupted upon activation. Membrane association is mediated upon $\mathrm{PIP}_{2}$ binding by the radixin $\mathrm{N}$-terminus, followed by phosphorylation of its C-terminus. The protein conformation changes to an open state, and the F-actin binding site becomes exposed. F-actin binding of radixin is essential for $\alpha 5$-containing $G_{A B A} R$ clustering. It is certainly interesting, why extrasynaptic receptors need clustering at certain locations instead of being equally distributed on the neuronal surface. Loebrich et al. discuss this point and hypothesize about potential neuronal-glial contact points in analogy to observations with the location of NMDA receptors (Loebrich et al., 2006). Glia cells are currently emerging as active players in information processing in addition to their supportive role for neurons (Dityatev and Rusakov, 2011). Small amounts of radixin and $\alpha 5$-containing receptors are also observed in gephyrin-positive synaptic areas where they might contribute to synaptic plasticity (Christie and de Blas, 2002).

Generally, gephyrin and radixin clustering are regarded as independent processes. Furthermore, those two proteins might still not tell the full story of $\mathrm{GABA}_{\mathrm{A}} \mathrm{R}$ clustering. Clusters of $\alpha 1$-containing receptors have also been observed in gephyrin knock-out mice. This phenomenon might reflect an unknown compensatory mechanism (e.g., other clustering factors or mechanisms), or a hypothetical $\mathrm{GABA}_{\mathrm{A}} \mathrm{R}$-intrinsic property (like receptor-receptor interactions) (Ghai et al., 2011).

Furthermore, it should be mentioned, that $\mathrm{GABA}_{\mathrm{A}} \mathrm{Rs}$ frequently contain mixed $\alpha$ or $\beta$ subunits (Benke et al., 2004). It is tempting to speculate that these "mixed" receptors have not only specific functional properties, but are also clustered in a special way. Mixed $\alpha 1-\alpha 5$ receptors might still be clustered by radixin. 
Alternatively, these receptors could also be clustered by gephyrin, if the $\alpha 1$ subunit is in a favorable configuration, maybe positioned adjacent to the $\gamma 2$ subunit. This could be an additional explanation for the low abundance, but not complete absence of $\alpha 5$-containing receptors at synaptic sites (Serwanski et al., 2006).

The characterization of gephyrin-binding sites on the $\alpha 1, \alpha 2$, and $\alpha 3$ subunits is only the starting point for understanding the $\mathrm{GABA}_{\mathrm{A}} \mathrm{R}$-gephyrin interactions. One aspect can be an additional interaction of gephyrin with other subunits of the $\mathrm{GABA}_{\mathrm{A}} \mathrm{R}$ pentamer. An association of gephyrin with extrasynaptic $\beta 3$ containing receptors during development and synaptogenesis has been described (Danglot et al., 2003). The authors suggest that $\beta 3$-containing receptors first appear in small clusters at the cell surface and only later on, when these receptors also contained $\gamma 2$ subunits, they become associated with synaptic sites. A supporting observation for this hypothesis might also be the fact that homozygous $\gamma 2$ knock-out mice are born alive and die only a few weeks after birth (Günther et al., 1995). Recently, a contribution of gephyrin to phasic as well as to tonic inhibition has been postulated (Marchionni et al., 2009).

\section{GEPHYRIN STRUCTURE, POLYMORPHISMS, AND ENZYMATIC ACTIVITY}

Gephyrin was initially recognized as a $93 \mathrm{kDa}$ protein copurifying with GlyR (Pfeiffer et al., 1982). The protein's first attributed function was a link of GlyR to microtubules (Langosch et al., 1992). Almost 400 papers have since been published on this $93 \mathrm{kDa}$ protein including the identification of a continuously increasing number of gephyrin-interacting proteins, still leaving us with a fragmented picture of how inhibitory post-synapses are organized and dynamically regulated with gephyrin as a central platform. Gephyrin is a phylogenetically old protein with 29 exons in mouse, appearing in multiple splice variants. These isoforms vary between species, tissues and maybe even cell types (Ramming et al., 2000).

In bacteria the main function of gephyrin is molybdenum cofactor (Moco) biosynthesis, which is essential for the activity of various metabolically important enzymes, like aldehyde oxidase, xanthine oxidoreductase, and sulfite oxidase. This biosynthetic activity, which is dependent on the presence of cassettes C2 and C6 has been maintained in higher organisms, in addition to the role of gephyrin in inhibitory neurotransmitter receptor clustering (Stallmeyer et al., 1999). The essential role of gephyrin in Moco biosynthesis in higher organisms is reflected in the fact that Moco-deficiency (independent of gephyrin) leads to neurodegeneration and Moco-deficient mice die at postnatal day 11 (Kügler et al., 2007). On the other hand, gephyrin knockout mice die immediately after birth (P0) with a stiff musculature that obviously results from an impaired GlyR function and absent motoneuron inhibition. The early postnatal death of gephyrin knock-out mice could not be prevented by restoring Moco biosynthesis in transgenic mice (Grosskreutz et al., 2003). Zebrafish contain duplicated gephyrin genes (GPHNA and $G P H N B)$ that are differentially distributed in tissues and both mediate Moco biosynthesis and GlyR clustering. Alternative splicing creates a high degree of variability that generates isoforms with diverse functions and properties (Ogino et al., 2011).
The importance of an intact GlyR-gephyrin system is illustrated by severe illnesses like Startle disease (hyperekplexia) showing neonatal hypertonia and an exaggerated startle reflex in response to auditory or tactile stimuli. This phenotype is mainly caused by multiple mutations of proteins involved in glycinergic neurotransmission, like GlyR, gephyrin, collybistin, and glycine transporters that also affect the GABAergic system (Harvey et al., 2008).

The most frequently mentioned splice variant $\mathrm{P} 1$ of gephyrin, first described by Prior et al. (1992), is composed of a $20 \mathrm{kDa}$ $\mathrm{N}$-terminal domain (G-domain: residues 1-181) and a Cterminal E-domain ( $43 \mathrm{kDa}$, residues 318-736), which are homologous to the bacterial Moco-synthesizing enzymes MogA and MoeA, respectively (Schwarz et al., 2001). In higher organisms the two domains are connected by a linker $(18-21 \mathrm{kDa})$, also referred to as C-domain (Feng et al., 1998). The G-domain has an intrinsic tendency to form trimers and, in vitro, the E-domains form dimers (Schwarz et al., 2001; Sola et al., 2001, 2004). As large gephyrin clusters appear at synapses and in light of the in vitro observations, an assumption of the presence of higher order structures ("super-structures") was postulated (Kirsch and Betz, 1995; Kneussel and Betz, 2000; Xiang et al., 2001). A longstanding hypothesis predicts a hexagonal lattice as a combination of the three-fold and two-fold symmetry elements (Kneussel and Betz, 2000). The authors present the hypothesis that gephyrin is initially present as trimers in the cytosol. The metastable characteristics of the E-domain prevents dimerization, but is stabilized upon GlyR binding and that the trimers are transported in vesicles to the synapse or are randomly inserted (Rosenberg et al., 2001; Hanus et al., 2004).

Some splice forms disrupt the formation of higher order structures like the $\mathrm{C} 5$ cassette in the G-domain, that prevents trimerization (Bedet et al., 2006). Gephyrin containing the C5 cassette can act as a dominant-negative variant that can still bind GlyRs, but favors diffusion of these receptors and removal from synapses. This model provides a hypothesis for a dynamic anchoring of receptors. A recent study provides more insight into biophysical properties of gephyrin (Herweg and Schwarz, 2012). The authors compared other isoforms (Gephyrin P1, GephyrinC3, Gephyrin-C4) in two expression systems: SF9 insect cells and human embryonic kidney-HEK cells. Geph-C3 is a non-neuronal form with the sole metabolic function of Moco biosynthesis. The C3 cassette is spliced by the neuronal factor Nova, which is absent in glia cells. Geph-C4 is a neuronal form that tends to accumulate at the plasma membrane, while Geph-C3 exhibits diffuse cytosolic staining in liver and glia cells. The choice of the expression system had an impact on which higher order structures could be identified by size exclusion chromatography: from E. coli trimeric gephyrin was isolated, while SF9 cells produced hexamers and even higher oligomeric complexes. The authors also looked at the dynamics of the subdomains. The G- and C-domain seem to stabilize each other, while the E-domain is more flexible remaining open for interactions with other proteins. Most gephyrin interaction partners bind close to or inside the E-domain.

It is well known, that gephyrin is a phosphoprotein. This posttranslational modification influences gephyrin clustering and also receptor binding (Zita et al., 2007; Bausen et al., 2010; Charrier 
et al., 2010). The comparison of the two expression systems allowed to further investigate the influence of different states of phosphorylation on gephyrin oligomerization. In addition to the previously characterized phosphorylation sites (Ser188, Ser194, Ser200, Ser270) Herweg and Schwarz added an additional 18 sites to the list, most of them located in the G-domain. These modifications can be expected to be celltype-specific and maybe also synapse-specific in higher organisms.

These studies mainly focus on GlyR-gephyrin interactions but are equally valuable for studying the interaction between gephyrin and $\mathrm{GABA}_{\mathrm{A}} \mathrm{Rs}$. The gephyrin variants might differ from synapse to synapse, but a mechanistic understanding of this complex system will help to better understand the interactions of gephyrin with $\mathrm{GABA}_{\mathrm{A}}$ Rs.

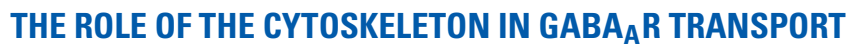 TO AND FROM THE NEURONAL SURFACE AND IN GEPHYRIN-MEDIATED CLUSTERING}

Neurotransmitter receptors are assembled in the ER/Golgi compartments and transported to the cell surface in membrane vesicles budding from the trans-Golgi along "trails" of the cytoskeleton. Specific motor proteins are responsible for the anterograde or retrograde transport. Gephyrin has been demonstrated to interact with microtubules, actin filaments and the microfilament system (Kirsch et al., 1995). Exon 14 of the murine gene of gephyrin contains a region that is highly homologous to motifs in the microtubule-associated proteins MAP2 and tau, which are essential for tubulin polymerization and microtubule binding. This could be the site of the direct interaction of gephyrin with tubulin. An indirect connection of gephyrin to microtubules is also mediated by adaptor proteins like KIF5 and the dynein light chains (DYNLL1/2) (Fuhrmann et al., 2002; Maas et al., 2009). The dynein components DNLL1/2 bind to gephyrin and mediate the retrograde transport of gephyrin-GlyR complexes (Fuhrmann et al., 2002).

Recombinant gephyrin has also been shown to interact with "uncapped" actin via the adaptor Mena/VASP (Mammalian enabled/Vasodilator stimulated phosphoprotein) (Bausen et al., 2006). A complex of profilin and actin-monomers is bound by Mena/VASP and increases the efficiency of actin polymerization. Actin filament formation and bundling is a prerequisite for morphological changes and dynamic cellular processes (Dent et al., 2011). The regulation of synaptic strength is usually accompanied by a change of the synaptic structure (Izeddin et al., 2011). Dendritic spines change their size and shape in response to synaptic activity (Penzes and Cahill, 2012). GABAergic synapses are mostly found on shafts, but will also depend on the microfilament system (Luccardini et al., 2004). A contribution of actin microfilaments in gephyrin clusters has been demonstrated by the observation that cytochalasin D, an inhibitor of actin polymerization and disruptor of actin microfilaments, disrupts small gephyrin clusters in the early stages of maturation of hippocampal neurons in culture (Bausen et al., 2006). The actin-binding protein profilin is an interactor of gephyrin (Mammoto et al., 1998). Profilin also binds membrane lipids like phosphatidyl $(4,5)$ bisphosphate. It is assumed that through binding to membranes profilin is kept in an inactive form that can be released by phospholipase C. Gephyrin actually competes with G-actin and phospholipids for the same binding site on profilin (Giesemann et al., 2003). The interplay of these proteins and the dynamics of the microfilament system at synaptic sites might play a role in receptor density and possibly in synaptic plasticity.

There are several cytoskeletal regulatory proteins that have been found to interact with gephyrin: some of those proteins are GEFs or GAPs of the Rho family of small GTPases: the Cdc42-GEF "ARHGEF9" (collybistin) (see below), the Rho-GAP "SRGAP2" (SLIT-ROBO Rho GTPase-activating protein 2) and the Rac-GAP "WRP" (WAVE-associated Rac GAP). WRP affects gephyrin cluster size and plays a role in a human $3 p$-syndrome mental retardation and mutations of this protein are also linked to schizophrenia (Endris et al., 2002; Lewis et al., 2008; Addington and Rapoport, 2009; Okada et al., 2011).

\section{COLLYBISTIN AND CELL ADHESION MOLECULES (CAMs) REGULATE GABAergic SYNAPSE FORMATION}

Collybistin is a member of the Dbl family of guanine nucleotide exchange factors (GEFs) and interacts with gephyrin (Grosskreutz et al., 2001). It is a RhoGEF for the small GTPase Cdc42 and is especially important for $\mathrm{GABA}_{\mathrm{A}} \mathrm{R}$-gephyrin clustering, as it seems to be a versatile modulator of this interaction (Kins et al., 2000). Small GTPases of the Rho family (Rho, Rac, Cdc42) are generally involved in establishing cellular polarity, transcriptional regulation, actin cytoskeleton rearrangements, intracellular trafficking, and endocytosis. They are activated by GEFs and inactivated by GAPs (GTPase activating proteins). The RhoGEF Kalirin has also been identified as an important signaling molecule at glutamatergic synapses and has been implicated in psychiatric diseases (Penzes et al., 2000; Penzes and Remmers, 2012). The involvement of RhoGEFs in cytoskeletal dynamics provides a compelling reason for their presence at dynamic synapses, as actin rearrangements will be involved in protein trafficking and synaptic stabilization. An interesting feature is the synapse-specificity of these proteins. It has been shown that collybistin exerts important functions in clustering of $\mathrm{GABA}_{\mathrm{A}} \mathrm{Rs}$ (Harvey et al., 2004).

Collybistin controls the sub-membrane accumulation and synaptic localization of gephyrin by translocating gephyrin from cytoplasmic aggregates to submembranous compartments. Collybistin knock-out mice reveal a region-specific loss of gephyrin and $\mathrm{GABA}_{\mathrm{A}} \mathrm{R}$ clusters in the hippocampus and amygdala, suggesting that gephyrin clustering might vary in different regions (Papadopoulos et al., 2007). Generally, these mice reveal a mild phenotype with no detectable impairment of gephyrin-GlyR clustering at glycinergic synapses. Collybistin occurs (speciesdependently) in different alternatively spliced forms. The main variants are currently named $\mathrm{CB}$ 1, 2, and 3 and are distinguished by their C-terminus. Change of splice variants and mutations in the gene frequently play a role in pathological states (Harvey et al., 2008). The RhoGEF activity seems not to be important for gephyrin clustering of $\mathrm{GABA}_{\mathrm{A}}$ Rs at synaptic sites. The only small GTPase, which is currently known to be associated with $\mathrm{CB}$ and gephyrin, Cdc42, is not vital for synapse formation and $\mathrm{GABA}_{A} \mathrm{R}$ gephyrin clustering (Reddy-Alla et al., 2010). CB2 and CB3 splice variants occur with or without a Src-homology-domain-3 (SH3): 
$\mathrm{CB}(\mathrm{SH} 3+)$ and $\mathrm{CB}(\mathrm{SH} 3-)$. The presence of the $\mathrm{SH} 3$-domain keeps $\mathrm{CB}$ in an inactive conformation that might be useful during intracellular transport, while $\mathrm{CB}(\mathrm{SH} 3-)$ isoforms are constitutively active in clustering gephyrin without the presence of an activating protein. The cell adhesion protein neuroligin-2 (NL-2) and the $\mathrm{GABA}_{\mathrm{A}} \mathrm{R} \alpha 2$ subunit can activate $\mathrm{CB}(\mathrm{SH} 3+)$ isoforms by binding to the SH3-domain (Poulopoulos et al., 2009; Saiepour et al., 2010). An attractive hypothesis for the sequence of events that leads to the establishment of the GABAergic postsynapse is presented in the review by Papadopoulos and Soykan (2011) in Frontiers.

Interesting features include the competition of NL-2 and $\mathrm{GABA}_{\mathrm{A}} \mathrm{R} \alpha 2$ subunits for the collybistin SH3-domain and the competition of collybistin and $\mathrm{GABA}_{\mathrm{A}} \mathrm{R} \alpha 2$ for slightly shifted, yet still overlapping sites on gephyrin (Tretter et al., 2011 and Figure 3C). The binding sites of $\mathrm{CB}$ and $\mathrm{GABA}_{\mathrm{A}} \mathrm{R}$ subunits $\alpha 2$ and $\alpha 3$ on gephyrin are positioned close to each other (see Figure 3). Saiepour et al. showed that the $G_{A B A} R \alpha 3$ subunit directly interacts with gephyrin, while $\alpha 2$, gephyrin and $\mathrm{CB}$ form a ternary complex, where CB strengthens the otherwise weak $\alpha 2$ gephyrin interaction (Saiepour et al., 2010). Therefore, synapses containing $\mathrm{GABA}_{\mathrm{A}} \mathrm{Rs}$ with an $\alpha 3$ subunit do not need collybistin as a cofactor, while collybistin is mandatory for synapses with $\alpha 2$-containing $\mathrm{GABA}_{\mathrm{A}}$ Rs (see Figures $2 \mathrm{~A}, \mathbf{B}$ ). The theory of a selective association of $\mathrm{CB}$ with certain $\mathrm{GABA}_{\mathrm{A}} \mathrm{R}$ subtypes has been rejected in the paper by Patrizi et al., yet the interaction of $\mathrm{CB}$ with the synaptic complexes seems to be only transient (Patrizi et al., 2011). Therefore, not all synaptic puncta are associated with CB immunoreactivity.

During synaptogenesis cell adhesion molecules like neurexin and neuroligin play very critical roles in stabilizing both excitatory and inhibitory synapses (Sudhof, 2008). Neurexin/Neuroligin knock-out mice exhibit significant behavioral phenotypes like memory deficits, hyperactive behavior or increased anxiety, revealing their importance in proper synaptogensis (Blundell et al., 2009, 2010). Other members of the CAM-family, the beta-integrins, have also been shown to be involved in gephyrinmediated GlyR dynamics at spinal cord synapses as intercellular interactors and downstream signaling receptors (Charrier et al., 2010). Whether they play a role in GABAergic synapses remains to be investigated. At the axon initial segment (AIS) the CAM neurofascin has been shown shown to organize $\mathrm{GABA}_{\mathrm{A}} \mathrm{R}$-gephyrin clusters in this area (Burkarth et al., 2007).

Recently, the cell adhesion molecule neuroplastin-65 of the immunoglobulin superfamily that is involved in hippocampal synaptic plasticity has also been shown to be associated with $\mathrm{GABA}_{\mathrm{A}}$ Rs containing $\alpha 1$ or $\alpha 2$, but not $\alpha 3$ subunits at GABAergic synapses (Sarto-Jackson et al., 2012). Here, neuroplastin-65 is partially colocalized with gephyrin. In addition, neuroplastin-65 also colocalizes with $\mathrm{GABA}_{\mathrm{A}} \mathrm{R} \alpha 5$ subunits at extra-synaptic sites. Down-regulation of neuroplastin- 65 by shRNA causes a loss of $\mathrm{GABA}_{\mathrm{A}} \mathrm{R} \alpha 2$ subunits at GABAergic synapses. These data indicated that neuroplastin-65 might contribute to anchoring and/or confining of a subset of $\mathrm{GABA}_{\mathrm{A}} \mathrm{R}$ subtypes to particular synaptic or extrasynaptic sites, thus affecting receptor mobility and synaptic strength. A possible direct interaction of neuroplastin-65 with gephyrin, collybistin, or radixin has not been investigated
(Sarto-Jackson et al., 2012). Given the many interaction partners of $\mathrm{GABA}_{\mathrm{A}} \mathrm{Rs}$, some of which have been identified only recently, a detailed understanding of the sequence of events during synaptogenesis including the role of different cell adhesion molecules is still missing.

Gephyrin has been shown to be bound to GlyRs already during the transport from the Golgi to the surface (Maas et al., 2006). Whether this is also the case with $G_{A B A}$ Rs is not known. Recently the protein Muskelin has been identified and characterized as an intracellular transport protein for $\mathrm{GABA}_{\mathrm{A}} \mathrm{R}$ (Heisler et al., 2011). An association of gephyrin with this complex has not yet been identified. In any case, the thoroughly documented constant dynamic synthesis, assembly, endocytosis and recycling process of $\mathrm{GABA}_{\mathrm{A}}$ Rs provides a large pool of available "free" receptors, either in intracellular vesicles waiting to be delivered to the cell surface, or already present in the plasma membrane at extrasynaptic sites. Overexpression of collybistin recruits those receptors into even more numerous and especially much larger synaptic clusters (Chiou et al., 2011). This would also represent a hypothetical model for GABAergic synaptic plasticity.

A new feature of gephyrin clustering at GABAergic synapses is the role of the heat-shock protein 70 (Hsp 70). This protein has been repeatedly identified as co-purifying with $\mathrm{GABA}_{\mathrm{A}}$ receptors (Moss et al., 1995). A recent paper describes a role of Hsp70 in the regulation of gephyrin clustering (Machado et al., 2011). Hsp70 seems to increase the synaptic accumulation of gephyrin at inhibitory synapses as well as gephyrin polymerization independently of the interaction with associated inhibitory neurotransmitter receptors. This observation probably needs further investigations to assess its significance.

\section{GEPHYRIN AS A HUB FOR SIGNAL TRANSDUCTION PATHWAYS TO THE NUCLEUS, INFLUENCING PROTEIN TRANSLATION}

The mammalian target of Rapamycin (mTOR)-pathway is a central signaling pathway that integrates input from external signals (like growth factors and insulin) but also cellular, nutritional, energy, and redox state and is frequently disregulated in cancer. There are two known complexes: mTOR1 and mTOR2. An abundance of growth factors and nutrients leads to the initiation of protein synthesis by mTOR1 and the stimulation of RhoA, Rac, Cdc42, and PKC by mTOR2. One component, RAFT1 has been identified as a gephyrin-interacting protein (Sabatini et al., 1999). The binding site of RAFT1 for gephyrin has $45 \%$ sequence similarity to the GlyR $\beta$ binding site. Therefore, the binding site on gephyrin might be roughly the same. RAFT1 (rapamycin and FKBP12 target-FRAP/mTOR) mediates drug actions of the immunosuppressant rapamycin and affects protein translation by phosphorylating the $70 \mathrm{kDa}$ S6 kinase, which in turn phosphorylates $4 \mathrm{E}-\mathrm{BP} 1$ (a repressor of protein translation initiation) and the ribosomal S6 protein. RAFT1 mutants that no longer interact with gephyrin do not signal to its downstream molecules. The functional consequences of this link between mTOR and gephyrin can be manifold and need further detailed investigations.

Gephyrin and collybistin have also been found as components of the eukaryotic translation initiation factor 3-complex-eIF3H (Sertie et al., 2010). This finding is rather surprising, but at the 
same time very interesting, as it implies a role of collybistin and gephyrin as regulators of local synaptic protein synthesis. Gephyrin might be the link to study local protein synthesis at GABAergic synapses.

\section{DYNAMICS AT GABAergic SYNAPSES: A MECHANISM OF PLASTICITY}

Neurotransmitter receptors do not sit still at the cell surface; many are highly mobile as they can diffuse very rapidly within the lipid membrane due to Brownian motion (Choquet and Triller, 2003). However, transient interactions with their specific scaffold proteins significantly slow down their movement resulting in a reduced rate of diffusion. Using quantum dots and further developments in sophisticated technology allow real-time observation of moving and synaptically trapped receptors and can generate very insightful information about protein-protein interaction (Bannai et al., 2006, 2009; Alcor et al., 2009). Data derived from single particle tracking (SPT) experiments can be particularly useful to understand weaker interactions where standard biochemical methods are of limited value (Triller and Choquet, 2008). Indeed SPT data provided critical insights into the scaffolding action of gephyrin when previously published data on the mobility of GlyRs or $\gamma 2$-containing $\mathrm{GABA}_{\mathrm{A}} \mathrm{Rs}$ were compared. The median diffusion coefficient (D) of endogenous $\gamma 2$-containing $\mathrm{GABA}_{\mathrm{A}} \mathrm{Rs}\left(0.012 \mu \mathrm{m}^{2} / \mathrm{s}\right)$ turned out to be approximately 10-fold higher compared to the diffusion coefficient derived for endogenous GlyRs on gephyrin puncta (Meier et al., 2001; Ehrensperger et al., 2007; Lévi et al., 2008). These data can be explained by a different strength of interaction with the cytoskeleton and are consistent with our finding that gephyrin binds at least 10 times stronger to GlyRs than to $\mathrm{GABA}_{\mathrm{A}} \mathrm{Rs}$. The higher mobility of $\mathrm{GABA}_{\mathrm{A}}$ Rs might be a prerequisite for different forms of synaptic plasticity at GABAergic synapses in the brain facilitating processes like learning and memory.

\section{GEPHYRIN MEDIATES TRANS-SYNAPTIC SIGNALING AND CROSSTALK WITH THE GLUTAMATERGIC SYSTEM}

Previous observations from the glutamatergic synapse already implicate that the multiple interactions of scaffold proteins renders them indispensible for up- and downstream signaling and crosstalk with other neurotransmitter systems. PSD-95, the main scaffold protein of glutamatergic synapses, has been shown to balance excitation and inhibition in the brain (Keith and El-Husseini, 2008). Varley and co-workers used single chain antibody fragments to remove gephyrin from synapses. They observed a reduction in the probability of GABA release from the presynaptic neuron. Additionally the frequency of spontaneous and miniature glutamatergic events was significantly reduced. A reduction of NL-2 and the vesicle transporters for GABA (VGAT) and glutamate (VGLUT) was also observed (Varley et al., 2011). This implies the initiation of a postsynaptic as well as a presynaptic signaling cascade upon interaction between neurexin and neuroligin. NL-2, which as described above, was shown to be physically interacting with gephyrin and collybistin is a nucleation factor for synapse formation and regulates synapse stability. It has also been demonstrated that presynaptic neurexin physically interacts with $\alpha 1-\mathrm{GABA}_{\mathrm{A}}$ Rs and can negatively modulate the inhibitory synaptic transmission in a neuroligin-independent pathway (Zhang et al., 2010). These data suggest that GABAergic synapse formation and maintenance are very complex processes and are regulated in multiple sophisticated ways. Regardless, our data demonstrate that the interaction between gephyrin and $\mathrm{GABA}_{\mathrm{A}} \mathrm{Rs}$ is very critical for the transient stability of mature synapses and dynamic modulation of this interaction can be very appropriate to tune the efficacy of inhibitory neurotransmission thus mediating synaptic plasticity. It is quite likely that mechanisms of gephyrin-mediated clustering of $\mathrm{GABA}_{\mathrm{A}} \mathrm{Rs}$ are not only dependent on the cell type but also on subcellular domains of neurons. Most investigations focus on dendritic clustering, however, $\mathrm{GABA}_{\mathrm{A}} \mathrm{R}$-gephyrin clusters also occur in (peri)somatic and axo-axonic synapses (Poulopoulos et al., 2009; Panzanelli et al., 2011). GABAergic synaptogenesis in different areas of the neuron (dendritic, somatic, axonal domains) most likely will be differentially regulated. This extends to different cell adhesion molecules and the contribution of other cofactors like the dystrophin-glycoprotein complex. In somatic areas gephyrin clusters are frequently observed to be smaller and probably only transient (Panzanelli et al., 2011).

\section{PHOSPHORYLATION CAN DYNAMICALLY REGULATE THE NUMBER OF POSTSYNAPTIC GABA $A$ Rs}

The number of receptors present at postsynaptic sites is not constant but changes over time. We assume that, like in many other biological processes, there is a natural random mobility of receptors and that in addition, their number at the synapse can be regulated dynamically depending on the cells' or system's needs (Wenner, 2011). Currently documented ways of regulating protein activity include site-specific phosphorylation, monoand polyubiquitination, sumoylation, acetylation, and proteolysis (Luscher et al., 2011). Neuronal activity can influence the confinement to anchoring proteins and the dwell time in microdomains of the synapse of the postsynaptic AMPA receptor, $\mathrm{GABA}_{\mathrm{A}} \mathrm{Rs}$, and GlyRs (Groc et al., 2004; Lévi et al., 2008). In many cases, neuronal activity-dependent phosphorylation regulates the interaction between scaffolding proteins and the synaptic receptors and thereby tunes synaptic strength (Muir et al., 2010).

Several studies have already shown that gephyrin is phosphorylated by many different kinases on several serines and threonines mostly in the linker (Zita et al., 2007; Bausen et al., 2010; Tyagarajan et al., 2011; Herweg and Schwarz, 2012). Phosphorylation of gephyrin is critical for the postsynaptic clustering of $\mathrm{GABA}_{\mathrm{A}} \mathrm{Rs}$. Tyagarajan et al. demonstrated that Ser270 of gephyrin is phosphorylated by GSK3 $\beta$. GSK3 $\beta$ activity can negatively modulate the clustering of $\mathrm{GABA}_{\mathrm{A}} \mathrm{Rs}$ and therefore, their function. Thus, abolishing phosphorylation at this residue resulted in a higher density of gephyrin clusters and a higher frequency of mIPSCs, an effect that could be induced by the GSK3 $\beta$ inhibitor and mood-stabilizing drug lithium (Tyagarajan et al., 2011). It is, however, interesting to note that the GSK3 $\beta$ phosphorylation site is located outside of the gephyrin E-domain, the domain that primarily mediates interactions with GlyRs and $\mathrm{GABA}_{\mathrm{A}}$ Rs. This modification apparently influences the folding and oligomerization of the gephyrin molecule. 
Where kinases are active players, matching phosphatases are usually not far away. Protein phosphatases 1 and 2B (PP1, PP2B) have been shown to associate with the gephyrin-platform and dephosphorylate gephyrin and associated proteins (Bausen et al., 2010). The phosphatase inhibitors calyculin A and ocadaic acid reduce the size of postsynaptic gephyrin clusters.

Gephyrin also undergoes proline-directed phosphorylation (on Ser/Thr-Pro consensus sites), followed by the recruitment of Pin1 (peptidyl-prolyl isomerase NIMA interacting protein1) that interacts with gephyrin in a phosphorylation-dependent manner (Zita et al., 2007). The binding site of Pin1 comprises Ser188, Ser194, and Ser200 that were found to be phosphorylated upon expression in SF9 cells (Herweg and Schwarz, 2012). Binding of Pin 1 induces a conformational change of gephyrin and enhances GlyR $\beta$ binding. Whether this plays a role also in $\mathrm{GABA}_{\mathrm{A}} \mathrm{R}$-gephyrin interactions remains to be determined.

There is strong evidence that phosphorylation of GlyRs and $\mathrm{GABA}_{\mathrm{A}}$ Rs also regulates their interaction with gephyrin. A PKC phosphorylation site in the intracellular loop of GlyR $\beta$ has been shown to negatively affect the binding affinity of gephyrin (Specht et al., 2011) (Figure 1C). A putative phosphorylation site (Thr375) has been identified in the gephyrin-binding site of the $\mathrm{GABA}_{\mathrm{A}} \mathrm{R} \alpha 1$ subunit (Mukherjee et al., 2011) (Figure 1C). Here, the introduction of a charged residue (aspartate) as a phosphomimetic significantly reduces the binding affinity to gephyrin.

The binding sites of $\mathrm{GABA}_{\mathrm{A}}$ receptor $\alpha 1, \alpha 2$, and $\alpha 3$ to gephyrin contain additional amino acids that could be kinase targets (Tretter et al., unpublished results). It can be anticipated that multiple and diverse phosphorylation events are involved in the dynamics of glycinergic and GABAergic synapses, regulating inhibitory synaptic plasticity.

\section{THE ROLE OF GEPHYRIN IN DISEASE}

A compromised function of $\mathrm{GABA}_{\mathrm{A}}$ Rs has been implicated in a range of neurological and psychiatric disorders, such as anxiety, insomnia, cognitive disorders, depression, epilepsy, and schizophrenia (Fritschy and Brunig, 2003). Generally spoken, epileptic seizures are believed to be conditions of imbalanced excitation and inhibition in certain brain areas that tend to progress with time involving pathologies like inflammation, necrosis, gliosis, etc. Early events are down-regulations of tonic GABA currents, loss of GABAergic interneurons and, therefore, alterations in neuronal circuit activities (Fritschy, 2008). The progression of the disease state can best be observed in animal models of temporal lobe epilepsy. Typical animal models are the kindling model and the pilocarpine injection. Fang et al. observed a reduction of immunostaining for gephyrin during both the acute and the latent period, followed by an increase during the chronic phase (Fang et al., 2011). As $\mathrm{GABA}_{\mathrm{A}} \mathrm{Rs}$ and gephyrin are functionally interdependent, the down-regulation of one of these proteins automatically also results in the loss of other partners or of other partner proteins at synapses. This might be the case during initial phases of the disease, where inhibition is disturbed either through functional overexcitation or a destruction of GABAergic interneurons and, therefore, lack of GABAergic input, and it might also be the case in a later upregulation, maybe as a neuronal attempt to increase the efficiency of inhibitory synapses (Andre et al., 2001).

Recently, an interesting observation was made concerning a possible specific role of gephyrin in epilepsy. Förstera et al. found a prevalence of alternatively spliced forms of gephyrin in brain tissue from drug-resistant mesial temporal lobe epilepsy patients (Forstera et al., 2010). Mesial temporal lobe epilepsy is a special form of focal epilepsy. The authors found four abnormally spliced gephyrin variants lacking several exons in the G-domain. As those exons are important in mediating gephyrin-gephyrin interaction, the oligomerization of the pathological forms of gephyrin is most likely impaired. Additionally they act in a dominant-negative way by interacting with regularly spliced gephyrin at synapses, thereby disrupting the normal gephyrin scaffold. Similar observations have been made experimentally in an earlier study (Calamai et al., 2009). Any fragment of gephyrin, that has the capability to assemble with endogenous gephyrin can act as a dominantnegative molecule interfering with the oligomerization process at the synapse. This affects cluster size and receptor mobility and finally synaptic strength. Mesial temporal lobe epilepsy frequently is a progressive illness. Patients usually have a history of risk factors like febrile seizures or other harmful triggers (Yang et al., 2010). As it is a multifactorial disease, the sequence of events is difficult to track down (Bozzi et al., 2011).

The role of collybistin as a cofactor in gephyrin clustering is emphasized by human disease states, where mutations of collybistin result in $\mathrm{X}$-linked mental retardation associated with epilepsy due to impaired $\mathrm{GABA}_{\mathrm{A}} \mathrm{R}$ clustering (Shimojima et al., 2011). Mutations in the human CB gene (ARHGEF9 on Xq11.1) were found in patients with diverse neurological abnormalities, including hyperekplexia, epilepsy, insomnia, aggressive behavior, and anxiety (Kalscheuer et al., 2009).

Although the sequence of molecular events in the course of developing $\mathrm{AD}$ is not yet resolved, one aspect might also be neuronal excitotoxicity contributing to synaptic degeneration and neuronal death. A reduced expression of gephyrin has been observed in all regions of brains from deceased $\mathrm{AD}$ patients (Agarwal et al., 2008). Loss of synaptic gephyrin also means a reduced neuronal inhibition and a higher susceptibility to excitotoxicity.

Loss of gephyrin is also the main problem in the autoimmune disease "Stiff man syndrome" where the body produces autoantibodies against gephyrin (Butler et al., 2000). The symptoms primarily reflect the dysfunction of GlyRs in the spinal cord.

\section{CONCLUSION AND OUTLOOK}

The strong interaction of gephyrin and GlyRs has provided an excellent model for the investigation of multiple aspects of the inhibitory postsynapse formation over the past 20 years. GlyRs and $\mathrm{GABA}_{\mathrm{A}}$ Rs are structurally related, but have distinct functions in the nervous system. The weaker interaction of $\mathrm{GABA}_{\mathrm{A}} \mathrm{Rs}$ with gephyrin as compared to GlyRs confers a higher mobility of $\mathrm{GABA}_{\mathrm{A}}$ Rs in synaptic areas, possibly requiring additional associated regulatory proteins. Knowledge on these associated proteins is slowly appearing. We are only beginning to understand, how GABAergic synapses are assembled. In addition, $\mathrm{GABA}_{\mathrm{A}} \mathrm{Rs}$ are 
much more heterogeneous than GlyRs with regard to the number of subunits and the subunit composition. Future research will have to investigate the interaction of individual $G_{A B A} R$ subtypes with gephyrin and other interacting proteins, the involvement of cofactors and synapse-specificity.

Gephyrin as the central scaffold is a protein with many faces. Its extensive heterogeneity through alternative splicing, posttranslational modifications and complex biophysical properties of its subdomains creates a multiplicity of structural scaffolds that can be used to accommodate and organize $\mathrm{GABA}_{\mathrm{A}} \mathrm{R}$ subtypes and associated proteins. Whether certain gephyrin isoforms confer synaptic specificity or control the dynamics at the synapse, currently is not known at present. A variety of proteins have recently been identified to interact with gephyrin and/or with $\mathrm{GABA}_{\mathrm{A}}$ Rs. Structural analysis should give the most reliable information on directly interacting proteins, but is still a huge technical

\section{REFERENCES}

Addington, A. M., and Rapoport, J. L. (2009). The genetics of childhoodonset schizophrenia: when madness strikes the prepubescent. Curr. Psychiatry Rep. 11, 156-161.

Agarwal, S., Tannenberg, R. K., and Dodd, P. R. (2008). Reduced expression of the inhibitory synapse scaffolding protein gephyrin in Alzheimer's disease. J. Alzheimers Dis. 14, 313-321.

Alcor, D., Gouzer, G., and Triller, A. (2009). Single-particle tracking methods for the study of membrane receptors dynamics. Eur. J. Neurosci. 30, 987-997.

Alldred, M. J., Mulder-Rosi, J., Lingenfelter, S. E., Chen, G., and Luscher, B. (2005). Distinct gamma2 subunit domains mediate clustering and synaptic function of postsynaptic GABAA receptors and gephyrin. J. Neurosci. 25, 594-603.

Andre, V., Marescaux, C., Nehlig, A., and Fritschy, J. M. (2001). Alterations of hippocampal GABAergic system contribute to development of spontaneous recurrent seizures in the rat lithium-pilocarpine model of temporal lobe epilepsy. Hippocampus 11, 452-468.

Baer, K., Essrich, C., Balsiger, S., Wick, M. J., Harris, R. A., Fritschy, J. M., and Luscher, B. (2000). Rescue of gamma2 subunit-deficient mice by transgenic overexpression of the GABAA receptor gamma2S or gamma2L subunit isoforms. Eur. J. Neurosci. 12, 2639-2643.

Bannai, H., Levi, S., Schweizer, C., Dahan, M., and Triller, A. (2006). Imaging the lateral diffusion of membrane molecules with quantum dots. Nat. Protoc. 1, 2628-2634.
Bannai, H., Levi, S., Schweizer, C., Inoue, T., Launey, T., Racine, V., Sibarita, J. B., Mikoshiba, K., and Triller, A. (2009). Activitydependent tuning of inhibitory neurotransmission based on GABAAR diffusion dynamics. Neuron 62, 670-682.

Barnard, E. A., Skolnick, P., Olsen, R. W., Mohler, H., Sieghart, W., Biggio, G., Braestrup, C., Bateson, A. N., and Langer, S. Z. (1998). International Union of Pharmacology. XV. Subtypes of gamma-aminobutyric acidA receptors: classification on the basis of subunit structure and receptor function. Pharmacol. Rev. 50, 291-313.

Barrera, N. P., and Edwardson, J. M. (2008). The subunit arrangement and assembly of ionotropic receptors. Trends Neurosci. 31, 569-576.

Baur, R., Kaur, K. H., and Sigel, E. (2010). Diversity of structure and function of alpha1alpha6beta3delta GABAA receptors: comparison with alphalbeta3delta and alpha6beta3delta receptors. J. Biol. Chem. 285, 17398-17405.

Bausen, M., Fuhrmann, J. C., Betz, H., and O'Sullivan, G. A. (2006). The state of the actin cytoskeleton determines its association with gephyrin: role of ena/VASP family members. Mol. Cell. Neurosci. 31, 376-386.

Bausen, M., Weltzien, F., Betz, H., and O’Sullivan, G. A. (2010). Regulation of postsynaptic gephyrin cluster size by protein phosphatase 1. Mol. Cell. Neurosci. 44, 201-209.

Bavro, V. N., Sola, M., Bracher, A., Kneussel, M., Betz, H., and Weissenhorn, W. (2002). Crystal structure of the GABA(A)-receptorassociated protein, GABARAP. EMBO Rep. 3, 183-189.

challenge for hetero-oligomeric receptors. The heterogeneity of $\mathrm{GABA}_{\mathrm{A}} \mathrm{Rs}$, gephyrin and cofactors provide a high flexibility for these synapses that for sure will play a role in synapse identity and synaptic plasticity.

\section{ACKNOWLEDGMENTS}

Many thanks to Patrick Rebernik for continuous IT support and help with graphical design and Carolyn Delto for graphical design. We would like to thank Kirsten and Robert Harvey for very constructive collaborations and members of the Werner Sieghart lab for their contributions to our work. Financial support by the Austrian Ministery of Science and Resarch and the EC FP7 project HEALTH-F4-2008-202088 (Neurocypres) (Werner Sieghart, Verena Tretter) is gratefully acknowledged. Work in the laboratory of Hermann Schindelin is supported by the Deutsche Forschungsgemeinschaft (FZ 82 and SFB 487 C7).

Bedet, C., Bruusgaard, J. C., Vergo, S., Groth-Pedersen, L., Eimer, S. Triller, A., and Vannier, C. (2006) Regulation of gephyrin assembly and glycine receptor synaptic stability. J. Biol. Chem. 281, 30046-30056.

Bedford, F. K., Kittler, J. T., Muller, E., Thomas, P., Uren, J. M., Merlo, D., Wisden, W., Triller, A., Smart, T. G., and Moss, S. J. (2001). GABA(A) receptor cell surface number and subunit stability are regulated by the ubiquitin-like protein Plic-1. Nat. Neurosci. 4, 908-916.

Bencsits, E., Ebert, V., Tretter, V., and Sieghart, W. (1999). A significant part of native gamma-aminobutyric AcidA receptors containing alpha4 subunits do not contain gamma or delta subunits. J. Biol. Chem. 274, 19613-19616.

Benke, D., Fakitsas, P., Roggenmoser, C., Michel, C., Rudolph, U., and Mohler, H. (2004). Analysis of the presence and abundance of GABAA receptors containing two different types of alpha subunits in murine brain using point-mutated alpha subunits. J. Biol. Chem. 279, 43654-43660.

Betz, H. (1998). Gephyrin, a major player in GABAergic postsynaptic membrane assembly? Nat. Neurosci. 1, 541-543.

Blundell, J., Blaiss, C. A., Etherton, M. R., Espinosa, F., Tabuchi, K., Walz, C., Bolliger, M. F., Sudhof, T. C., and Powell, C. M. (2010). Neuroligin1 deletion results in impaired spatial memory and increased repetitive behavior. J. Neurosci. 30, 2115-2129.

Blundell, J., Tabuchi, K., Bolliger, M. F., Blaiss, C. A., Brose, N., Liu, X., Sudhof, T. C., and Powell, C. M. (2009). Increased anxietylike behavior in mice lacking the inhibitory synapse cell adhesion molecule neuroligin 2. Genes Brain Behav. 8, 114-126.

Bollan, K., King, D., Robertson, L. A., Brown, K., Taylor, P. M., Moss, S. J., and Connolly, C. N. (2003). $\mathrm{GABA}(\mathrm{A})$ receptor composition is determined by distinct assembly signals within alpha and beta subunits. J. Biol. Chem. 278, 4747-4755.

Bozzi, Y., Dunleavy, M., and Henshall, D. C. (2011). Cell signaling underlying epileptic behavior. Front. Behav. Neurosci. 5:45. doi: 10.3389/fnbeh.2011.00045

Brandon, N. J., Jovanovic, J. N., Colledge, M., Kittler, J. T., Brandon, J. M., Scott, J. D., and Moss, S. J. (2003). A-kinase anchoring protein $79 / 150$ facilitates the phosphorylation of $\operatorname{GABA}(\mathrm{A})$ receptors by cAMP-dependent protein kinase via selective interaction with receptor beta subunits. Mol. Cell. Neurosci. 22, 87-97.

Brandon, N. J., Jovanovic, J. N., Smart, T. G., and Moss, S. J. (2002). Receptor for activated C kinase-1 facilitates protein kinase $\mathrm{C}$-dependent phosphorylation and functional modulation of $\operatorname{GABA}(\mathrm{A})$ receptors with the activation of G-protein-coupled receptors. J. Neurosci. 22, 6353-6361.

Burkarth, N., Kriebel, M., Kranz, E. U., and Volkmer, H. (2007). Neurofascin regulates the formation of gephyrin clusters and their subsequent translocation to the axon hillock of hippocampal neurons. Mol. Cell. Neurosci. 36, 59-70.

Butler, M. H., Hayashi, A., Ohkoshi, N., Villmann, C., Becker, C. M., Feng, G., de Camilli, P., and Solimena, M. (2000). Autoimmunity to gephyrin in Stiff-Man syndrome. Neuron 26, 307-312. 
Calamai, M., Specht, C. G., Heller, J., Alcor, D., Machado, P., Vannier, C., and Triller, A. (2009). Gephyrin oligomerization controls GlyR mobility and synaptic clustering. J. Neurosci. 29, 7639-7648.

Charrier, C., Machado, P., TweedieCullen, R. Y., Rutishauser, D., Mansuy, I. M., and Triller, A. (2010). A crosstalk between betal and beta3 integrins controls glycine receptor and gephyrin trafficking at synapses. Nat. Neurosci. 13, 1388-1395.

Chiou, T. T., Bonhomme, B., Jin, H., Miralles, C. P., Xiao, H., Fu, Z., Harvey, R. J., Harvey, K., Vicini, S., and de Blas, A. L. (2011). Differential regulation of the postsynaptic clustering of gammaaminobutyric acid type A (GABAA) receptors by collybistin isoforms. J. Biol. Chem. 286, 22456-22468.

Choquet, D., and Triller, A. (2003). The role of receptor diffusion in the organization of the postsynaptic membrane. Nat. Rev. Neurosci. 4 , 251-265.

Christie, S. B., and de Blas, A. L. (2002). alpha5 Subunit-containing GABA(A) receptors form clusters at GABAergic synapses in hippocampal cultures. Neuroreport 13, 2355-2358.

Christie, S. B., Li, R. W., Miralles, C. P., Yang, B. Y., and de Blas, A. L. (2006). Clustered and nonclustered GABAA receptors in cultured hippocampal neurons. Mol. Cell. Neurosci. 31, 1-14.

Connolly, C. N., Krishek, B. J., McDonald, B. J., Smart, T. G., and Moss, S. J. (1996). Assembly and cell surface expression of heteromeric and homomeric gamma-aminobutyric acid type A receptors. J. Biol. Chem. 271, 89-96.

Danglot, L., Triller, A., and Bessis, A. (2003). Association of gephyrin with synaptic and extrasynaptic GABAA receptors varies during development in cultured hippocampal neurons. Mol. Cell. Neurosci. 23, 264-278.

Dent, E. W., Merriam, E. B., and Hu, X. (2011). The dynamic cytoskeleton: backbone of dendritic spine plasticity. Curr. Opin. Neurobiol. 21, 175-181.

Dityatev, A., and Rusakov, D. A. (2011). Molecular signals of plasticity at the tetrapartite synapse. Curr. Opin. Neurobiol. 21, 353-359.

Ehrensperger, M. V., Hanus, C., Vannier, C., Triller, A., and Dahan, M. (2007). Multiple association states between glycine receptors and gephyrin identified by SPT analysis. Biophys. J. 92, 3706-3718.
Ehya, N., Sarto, I., Wabnegger, L., and Sieghart, W. (2003). Identification of an amino acid sequence within GABA(A) receptor beta3 subunits that is important for receptor assembly. J. Neurochem. 84, 127-135.

Endris, V., Wogatzky, B., Leimer, U., Bartsch, D., Zatyka, M., Latif, F., Maher, E. R., Tariverdian, G., Kirsch, S., Karch, D., and Rappold, G. A. (2002). The novel RhoGTPase activating gene MEGAP/ srGAP3 has a putative role in severe mental retardation. Proc. Natl. Acad. Sci. U.S.A. 99, 11754-11759.

Essrich, C., Lorez, M., Benson, J. A., Fritschy, J. M., and Luscher, B. (1998). Postsynaptic clustering of major GABAA receptor subtypes requires the gamma 2 subunit and gephyrin. Nat. Neurosci. 1, 563-571.

Fang, M., Shen, L., Yin, H., Pan, Y. M., Wang, L., Chen, D., Xi, Z. Q., Xiao, Z., Wang, X. F., and Zhou, S. N. (2011). Downregulation of gephyrin in temporal lobe epilepsy neurons in humans and a rat model. Synapse 65, 1006-1014.

Farrant, M., and Nusser, Z. (2005). Variations on an inhibitory theme: phasic and tonic activation of GABA(A) receptors. Nat. Rev. Neurosci. 6, 215-229.

Feng, G., Tintrup, H., Kirsch, J., Nichol, M. C., Kuhse, J., Betz, H., and Sanes, J. R. (1998). Dual requirement for gephyrin in glycine receptor clustering and molybdoenzyme activity. Science 282, 1321-1324.

Forstera, B., Belaidi, A. A., Juttner, R., Bernert, C., Tsokos, M., Lehmann, T. N., Horn, P., Dehnicke, C., Schwarz, G., and Meier, J. C. (2010). Irregular RNA splicing curtails postsynaptic gephyrin in the cornu ammonis of patients with epilepsy. Brain 133, 3778-3794.

Fritschy, J. M. (2008). Epilepsy, E/I Balance and GABA(A) Receptor Plasticity. Front. Mol. Neurosci. 1:5. doi: 10.3389/neuro.02.005.2008

Fritschy, J. M., and Brunig, I. (2003). Formation and plasticity of GABAergic synapses: physiological mechanisms and pathophysiological implications. Pharmacol. Ther. 98, 299-323.

Fuhrmann, J. C., Kins, S., Rostaing, P., El Far, O., Kirsch, J., Sheng, M., Triller, A., Betz, H., and Kneussel, M. (2002). Gephyrin interacts with Dynein light chains 1 and 2, components of motor protein complexes. $J$. Neurosci. 22, 5393-5402.

Funayama, N., Nagafuchi, A., Sato, N., and Tsukita, S. (1991). Radixin is a novel member of the band
4.1 family. J. Cell Biol. 115, 1039-1048.

Ghai, R., Mobli, M., Norwood, S. J., Bugarcic, A., Teasdale, R. D., King, G. F., and Collins, B. M (2011). Phox homology band 4.1/ezrin/radixin/moesin-like proteins function as molecular scaffolds that interact with cargo receptors and Ras GTPases. Proc. Natl. Acad. Sci. U.S.A. 108, 7763-7768.

Giesemann, T., Schwarz, G., Nawrotzki, R., Berhörster, K., Rothkegel, M., Schlüter, K., Schrader, N., Schindelin, H., Mendel, R. R., Kirsch, J., and Jockusch, B. M (2003). Complex formation between the postsynaptic scaffolding protein gephyrin, profilin, and Mena: a possible link to the microfilament system. J. Neurosci. 23, 8330-8339.

Goto, H., Terunuma, M., Kanematsu, T., Misumi, Y., Moss, S. J., and Hirata, M. (2005). Direct interaction of N-ethylmaleimide-sensitive factor with $\operatorname{GABA}(\mathrm{A})$ receptor beta subunits. Mol. Cell. Neurosci. 30, 197-206.

Groc, L., Heine, M., Cognet, L. Brickley, K., Stephenson, F. A., Lounis, B., and Choquet, D. (2004) Differential activity-dependent regulation of the lateral mobilities of AMPA and NMDA receptors. Nat. Neurosci. 7, 695-696.

Grosskreutz, Y., Betz, H., and Kneussel, M. (2003). Rescue of molybdenum cofactor biosynthesis in gephyrindeficient mice by a Cnxl transgene. Biochem. Biophys. Res. Commun 301, 450-455.

Grosskreutz, Y., Hermann, A., Kins, S., Fuhrmann, J. C., Betz, H., and Kneussel, M. (2001). Identification of a gephyrin-binding motif in the GDP/GTP exchange factor collybistin. Biol. Chem. 382, 1455-1462.

Günther, U., Benson, J., Benke, D., Fritschy, J. M., Reyes, G., Knoflach, F., Crestani, F., Aguzzi, A., Arigoni, M., Lang, Y., Bluethmann, H., Mohler, H., and Luscher, B. (1995) Benzodiazepine-insensitive mice generated by targeted disruption of the gamma 2 subunit gene of gamma-aminobutyric acid type A receptors. Proc. Natl. Acad. Sci. U.S.A. 92, 7749-7753.

Hanley, J. G., Koulen, P., Bedford, F., Gordon-Weeks, P. R., and Moss, S. J. (1999). The protein MAP$1 B$ links $\operatorname{GABA}(\mathrm{C})$ receptors to the cytoskeleton at retinal synapses. Nature 397, 66-69.

Hanus, C., Vannier, C., and Triller, A. (2004). Intracellular association of glycine receptor with gephyrin increases its plasma membrane accumulation rate. J. Neurosci. 24, 1119-1128.

Harvey, K., Duguid, I. C., Alldred, M. J., Beatty, S. E., Ward, H., Keep, N. H., Lingenfelter, S. E., Pearce, B. R., Lundgren, J., Owen, M. J., Smart, T. G., Lüscher, B., Rees, M. I., and Harvey, R. J. (2004). The GDPGTP exchange factor collybistin: an essential determinant of neuronal gephyrin clustering. J. Neurosci. 24, 5816-5826.

Harvey, R. J., Topf, M., Harvey, K., and Rees, M. I. (2008). The genetics of hyperekplexia: more than startle! Trends Genet. 24, 439-447.

Heisler, F. F., Loebrich, S., Pechmann, Y., Maier, N., Zivkovic, A. R., Tokito, M., Hausrat, T. J., Schweizer, M., Bahring, R., Holzbaur, E. L., Schmitz, D., and Kneussel, M. (2011). Muskelin regulates actin filament- and microtubule-based GABA(A) receptor transport in neurons. Neuron 70, 66-81.

Herweg, J., and Schwarz, G. (2012). Splice-specific glycine receptor binding, folding, and phosphorylation of the scaffolding protein gephyrin. J. Biol. Chem. 287, 12645-12656.

Izeddin, I., Specht, C. G., Lelek, M., Darzacq, X., Triller, A., Zimmer, C., and Dahan, M. (2011). Superresolution dynamic imaging of dendritic spines using a lowaffinity photoconvertible actin probe. PLOS ONE 17:6. doi: 10.1371/journal.pone.0015611

Jacob, T. C., Moss, S. J., and Jurd, R. (2008). GABA(A) receptor trafficking and its role in the dynamic modulation of neuronal inhibition. Nat. Rev. Neurosci. 9, 331-343.

Jemth, P., and Gianni, S. (2007). PDZ domains: folding and binding. Biochemistry 46, 8701-8708.

Kalscheuer, V. M., Musante, L., Fang, C., Hoffmann, K., Fuchs, C., Carta, E., Deas, E., Venkateswarlu, K., Menzel, C., Ullmann, R., Tommerup, N., Dalpra, L., Tzschach, A., Selicorni, A., Luscher, B., Ropers, H. H., Harvey, K., and Harvey, R. J. (2009). A balanced chromosomal translocation disrupting ARHGEF9 is associated with epilepsy, anxiety, aggression, and mental retardation. Hum Mutat. 30, 61-68.

Kanematsu, T., Yasunaga, A., Mizoguchi, Y., Kuratani, A., Kittler, J. T., Jovanovic, J. N., Takenaka, K., Nakayama, K. I., Fukami, K., Takenawa, T., Moss, S. J., Nabekura, J., and Hirata, M. (2006). Modulation of GABA(A) receptor 
phosphorylation and membrane trafficking by phospholipase Crelated inactive protein/protein phosphatase 1 and $2 \mathrm{~A}$ signaling complex underlying brain-derived neurotrophic factor-dependent regulation of GABAergic inhibition. J. Biol. Chem. 281, 22180-22189.

Kasugai, Y., Swinny, J. D., Roberts, J. D., Dalezios, Y., Fukazawa, Y., Sieghart, W., Shigemoto, R., and Somogyi, P. (2010). Quantitative localisation of synaptic and extrasynaptic GABAA receptor subunits on hippocampal pyramidal cells by freeze-fracture replica immunolabelling. Eur. J. Neurosci. 32, 1868-1888.

Kaur, K. H., Baur, R., and Sigel, E. (2009). Unanticipated structural and functional properties of deltasubunit-containing GABAA receptors. J. Biol. Chem. 284, 7889-7896.

Keith, D., and El-Husseini, A. (2008). Excitation control: balancing PSD-95 function at the synapse. Front. Mol. Neurosci. 1:4. doi: 10.3389/neuro.02.004.2008

Kim, E. Y., Schrader, N., Smolinsky, B., Bedet, C., Vannier, C., Schwarz, G., and Schindelin, H. (2006). Deciphering the structural framework of glycine receptor anchoring by gephyrin. $E M B O$ J. 25, 1385-1395.

Kins, S., Betz, H., and Kirsch, J. (2000). Collybistin, a newly identified brain-specific GEF, induces submembrane clustering of gephyrin. Nat. Neurosci. 3, 22-29.

Kirsch, J., and Betz, H. (1995). The postsynaptic localization of the glycine receptor-associated protein gephyrin is regulated by the cytoskeleton. J. Neurosci. 15, 4148-4156.

Kirsch, J., Kuhse, J., and Betz, H. (1995). Targeting of glycine receptor subunits to gephyrin-rich domains in transfected human embryonic kideny cells. Mol. Cell. Neurosci. 6, 450-461.

Kittler, J. T., Rostaing, P., Schiavo, G., Fritschy, J. M., Olsen, R., Triller, A., and Moss, S. J. (2001). The subcellular distribution of GABARAP and its ability to interact with NSF suggest a role for this protein in the intracellular transport of GABA(A) receptors. Mol. Cell. Neurosci. 18, 13-25.

Klausberger, T., Roberts, J. D., and Somogyi, P. (2002). Cell typeand input-specific differences in the number and subtypes of synaptic GABA(A) receptors in the hippocampus. J. Neurosci. 22, 2513-2521.

Klausberger, T., Sarto, I., Ehya, N., Fuchs, K., Furtmuller, R., Mayer, B.,
Huck, S., and Sieghart, W. (2001). Alternate use of distinct intersubunit contacts controls GABAA receptor assembly and stoichiometry. J. Neurosci. 21, 9124-9133.

Klausberger, T., Fuchs, K., Mayer, B., Ehya, N., and Sieghart, W. (2000). GABA(A) receptor assembly. Identification and structure of gamma(2) sequences forming the inter-subunit contacts with alpha(1) and beta(3) subunits. J. Biol. Chem. 275, 8921-8928.

Kneussel, M., and Betz, H. (2000). Clustering of inhibitory neurotransmitter receptors at developing postsynaptic sites: the membrane activation model. Trends Neurosci. 23, 429-435.

Kneussel, M., Haverkamp, S., Fuhrmann, J. C., Wang, H., Wässle, H., Olsen, R. W., and Betz, H. (2000). The gamma-aminobutyric acid type A receptor (GABAAR)associated protein GABARAP interacts with gephyrin but is not involved in receptor anchoring at the synapse. Proc. Natl. Acad. Sci. U.S.A. 97, 8594-8599.

Kneussel, M. (2005). Postsynaptic scaffold proteins at non-synaptic sites. The role of postsynaptic scaffold proteins in motor-protein-receptor complexes. EMBO Rep. 6, 22-27.

Kneussel, M., Brandstatter, J. H., Laube, B., Stahl, S., Muller, U., and Betz, H. (1999). Loss of postsynaptic GABA(A) receptor clustering in gephyrin-deficient mice. J. Neurosci. 19, 9289-9297.

Kügler, S., Hahnewald, R., Garrido, M., and Reiss, J. (2007). Long-term rescue of a lethal inherited disease by adeno-associated virus-mediated gene transfer in a mouse model of molybdenum-cofactor deficiency. Am. J. Hum. Genet. 80, 291-297.

Langosch, D., Hoch, W., and Betz, H. (1992). The $93 \mathrm{kDa}$ protein gephyrin and tubulin associated with the inhibitory glycine receptor are phosphorylated by an endogenous protein kinase. FEBS Lett. 298, 113-117.

Lewis, D. A., Hashimoto, T., and Morris, H. M. (2008). Cell and receptor type-specific alterations in markers of GABA neurotransmission in the prefrontal cortex of subjects with schizophrenia. Neurotox. Res. 14, 237-248.

Loebrich, S., Bahring, R., Katsuno, T., Tsukita, S., and Kneussel, M. (2006). Activated radixin is essential for GABAA receptor alpha5 subunit anchoring at the actin cytoskeleton. EMBO J. 25, 987-999.

Luccardini, C., Casagrande, S., Cupello, A., Pellistri, F., Ramoino, P., and
Robello, M. (2004). The combined disruption of microfilaments and microtubules affects the distribution and function of $\mathrm{GABA}_{\mathrm{A}}$ receptors in rat cerebellum granule cells in culture. Neurosci. Lett. 359 25-28.

Luscher, B., Fuchs, T., and Kilpatrick, C. L. (2011). GABAA receptor trafficking-mediated plasticity of inhibitory synapses. Neuron 70, 385-409.

Lévi, S., Schweizer, C., Bannai, H., Pascual, O., Charrier, C., and Triller, A. (2008). Homeostatic regulation of synaptic GlyR numbers driven by lateral diffusion. Neuron 59 , 261-273.

Maas, C., Belgardt, D., Lee, H. K., Heisler, F. F., Lappe-Siefke, C., Magiera, M. M., van Dijk, J. Hausrat, T. J., Janke, C., and Kneussel, M. (2009). Synaptic activation modifies microtubules underlying transport of postsynaptic cargo. Proc. Natl. Acad. Sci. U.S.A. 106, 8731-8736.

Maas, C., Tagnaouti, N., Loebrich, S., Behrend, B., Lappe-Siefke, C. and Kneussel, M. (2006). Neurona cotransport of glycine receptor and the scaffold protein gephyrin. J. Cell. Biol. 172, 441-451.

Machado, P., Rostaing, P., Guigonis, J. M., Renner, M., Dumoulin, A. Samson, M., Vannier, C., and Triller A. (2011). Heat shock cognate protein 70 regulates gephyrin clustering. J. Neurosci. 31, 3-14.

Mammoto, A., Sasaki, T., Asakura, T., Hotta, I., Imamura, H., Takahashi, K., Matsuura, Y., Shirao, T., and Takai, Y. (1998). Interactions of drebrin and gephyrin with profilin Biochem. Biophys. Res. Commun. 243, 86-89.

Marchionni, I., Kasap, Z., Mozrzymas, J. W., Sieghart, W., Cherubini, E., and Zacchi, P. (2009). New insights on the role of gephyrin in regulating both phasic and tonic GABAergic inhibition in rat hippocampal neurons in culture. Neuroscience 164 552-562.

Maric, H. M., Mukherjee, J., Tretter, V., Moss, S. J., and Schindelin, H. (2011). Gephyrin-mediated GABA(A) and glycine receptor clustering relies on a common binding site. J. Biol. Chem. 286, 42105-42114.

Martin, L. J., Bonin, R. P., and Orser, B. A. (2009). The physiological properties and therapeutic potential of alpha5-GABAA receptors. Biochem. Soc. Trans. 37, 1334-1337.

Meier, J., and Grantyn, R. (2004). Preferential accumulation of GABAA receptor gamma $2 \mathrm{~L}$, not gamma 2 , cytoplasmic loops at rat spinal cord inhibitory synapses. J. Physiol. 559(Pt 2), 355-365.

Meier, J., Vannier, C., Sergé, A., Triller, A., and Choquet, D. (2001). Fast and reversible trapping of surface glycine receptors by gephyrin. Nat. Neurosci. 4, 253-260.

Mortensen, M., Ebert, B., Wafford, K., and Smart, T. G. (2010). Distinct activities of GABA agonists at synaptic- and extrasynaptic-type GABAA receptors. J. Physiol. 588, 1251-1268.

Moss, S. J., Gorrie, G. H., Amato, A., and Smart, T. G. (1995) Modulation of GABAA receptors by tyrosine phosphorylation. Nature 377, 344-348.

Moss, S. J., and Smart, T. G. (2001). Constructing inhibitory synapses. Nat. Rev. Neurosci. 2, 240-250.

Muir, J., Arancibia-Carcamo, I. L., MacAskill, A. F., Smith, K. R., Griffin, L. D., and Kittler, J. T. (2010). NMDA receptors regulate GABAA receptor lateral mobility and clustering at inhibitory synapses through serine 327 on the $\gamma 2$ subunit. Proc. Natl. Acad. Sci. U.S.A. 107, 16679-16684.

Mukherjee, J., Kretschmannova, K., Gouzer, G., Maric, H. M., Ramsden, S., Tretter, V., Harvey, K., Davies, P. A., Triller, A., Schindelin, H., and Moss, S. J. (2011). The residence time of GABAARs at inhibitory synapses is determined by direct binding of the receptor \{alpha\} 1 subunit to gephyrin. J. Neurosci. 31, 14677-14687.

Nusser, Z., Sieghart, W., and Somogyi, P. (1998). Segregation of different GABAA receptors to synaptic and extrasynaptic membranes of cerebellar granule cells. J. Neurosci. 18, 1693-1703.

O'Sullivan, G. A., Kneussel, M., Elazar, Z., and Betz, H. (2005). GABARAP is not essential for GABA receptor targeting to the synapse. Eur. J. Neurosci. 22, 2644-2648.

Ogino, K., Ramsden, S. L., Keib, N., Schwarz, G., Harvey, R. J., and Hirata, H. (2011). Duplicated gephyrin genes showing distinct tissue distribution and alternative splicing patterns mediate molybdenum cofactor biosynthesis, glycine receptor clustering, and escape behavior in zebrafish. J. Biol. Chem 286, 806-817.

Okada, H., Uezu, A., Mason, F. M., Soderblom, E. J., Moseley, M. A. 3rd, and Soderling, S. H. (2011). SH3 domain-based phototrapping in living cells reveals Rho family GAP signaling complexes. Sci. Signal. 4, rs13. 
Olsen, R. W., and Sieghart, W. (2008). International Union of Pharmacology. LXX. Subtypes of gamma-aminobutyric acid(A) receptors: classification on the basis of subunit composition, pharmacology, and function. Update. Pharmacol. Rev. 60, 243-260.

Panzanelli, P., Gunn, B. G., Schlatter, M. C., Benke, D., Tyagarajan, S. K., Scheiffele, P., Belelli, D., Lambert, J. J., Rudolph, U., and Fritschy, J. M. (2011). Distinct mechanisms regulate GABAA receptor and gephyrin clustering at perisomatic and axo-axonic synapses on CA1 pyramidal cells. J. Physiol. 589, 4959-4980.

Papadopoulos, T., Korte, M., Eulenburg, V., Kubota, H., Retiounskaia, M., Harvey, R. J., Harvey, K., O'Sullivan, G. A., Laube, B., Hulsmann, S., Geiger, J. R., and Betz, H. (2007). Impaired GABAergic transmission and altered hippocampal synaptic plasticity in collybistin-deficient mice. EMBO J. 26, 3888-3899.

Papadopoulos, T., and Soykan, T. (2011). The role of collybistin in gephyrin clustering at inhibitory synapses: facts and open questions. Front. Cell. Neurosci. 5:11. doi: 10.3389/fncel.2011.00011

Patrizi, A., Viltono, L., Frola, E., Harvey, K., Harvey, R. J., and Sassoe-Pognetto, M. (2011). Selective localization of collybistin at a subset of inhibitory synapses in brain circuits. J. Comp. Neurol. 520, 130-141.

Penzes, P., and Remmers, C. (2012). Kalirin signaling: implications for synaptic pathology. Mol. Neurobiol. 45, 109-118.

Penzes, P., and Cahill, M. E. (2012). Deconstructing signal transduction pathways that regulate the actin cytoskeleton in dendritic spines. Cytoskeleton (Hoboken). [Epub ahead of print].

Penzes, P., Johnson, R. C., Alam, M. R., Kambampati, V., Mains, R. E., and Eipper, B. A. (2000). An isoform of kalirin, a brain-specific GDP/GTP exchange factor, is enriched in the postsynaptic density fraction. J. Biol. Chem. 275, 6395-6403.

Pfeiffer, F., Graham, D., and Betz, H. (1982). Purification by affinity chromatography of the glycine receptor of rat spinal cord. J. Biol. Chem. 257, 9389-9393.

Poulopoulos, A., Aramuni, G., Meyer, G., Soykan, T., Hoon, M., Papadopoulos, T., Zhang, M., Paarmann, I., Fuchs, C., Harvey, K., Jedlicka, P., Schwarzacher, S. W, Betz, H., Harvey, R. J., Brose,
N., Zhang, W. and Varoqueaux, F. (2009). Neuroligin 2 drives postsynaptic assembly at perisomatic inhibitory synapses through gephyrin and collybistin. Neuron 63, 628-642.

Prior, P., Schmitt, B., Grenningloh, G., Pribilla, I., Multhaup, G., Beyreuther, K., Maulet, Y., Werner, P., Langosch, D., Kirsch, J., and Betz, H. (1992). Primary structure and alternative splice variants of gephyrin, a putative glycine receptortubulin linker protein. Neuron 8, 1161-1170.

Ramming, M., Kins, S., Werner, N., Hermann, A., Betz, H., and Kirsch, J. (2000). Diversity and phylogeny of gephyrin: tissue-specific splice variants, gene structure, and sequence similarities to molybdenum cofactor-synthesizing and cytoskeleton-associated proteins. Proc. Natl. Acad. Sci. U.S.A. 97, 10266-10271.

Reddy-Alla, S., Schmitt, B., Birkenfeld, J., Eulenburg, V., Dutertre, S., Bohringer, C., Gotz, M., Betz, H., and Papadopoulos, T. (2010). PH-domain-driven targeting of collybistin but not Cdc42 activation is required for synaptic gephyrin clustering. Eur. J. Neurosci. 31, 1173-1184.

Rosenberg, M., Meier, J., Triller, A., and Vannier, C. (2001). Dynamics of glycine receptor insertion in the neuronal plasma membrane. J. Neurosci. 21, 5036-5044.

Rudolph, U., and Mohler, H. (2004). Analysis of GABAA receptor function and dissection of the pharmacology of benzodiazepines and general anesthetics through mouse genetics. Annu. Rev. Pharmacol. Toxicol. 44, 475-498.

Sabatini, D. M., Barrow, R. K., Blackshaw, S., Burnett, P. E., Lai, M. M., Field, M. E., Bahr, B. A., Kirsch, J., Betz, H., and Snyder, S. H. (1999). Interaction of RAFT1 with gephyrin required for rapamycin-sensitive signaling. Science 284, 1161-1164.

Saiepour, L., Fuchs, C., Patrizi, A., Sassoe-Pognetto, M., Harvey, R. J., and Harvey, K. (2010). Complex role of collybistin and gephyrin in GABAA receptor clustering. J. Biol. Chem. 285, 29623-29631.

Sarto, I., Wabnegger, L., Dögl, E., and Sieghart, W. (2002). Homologous sites of GABA(A) receptor alpha(1), beta(3) and gamma(2) subunits are important for assembly. Neuropharmacology 43, 482-491.

Sarto-Jackson, I., Ramerstorfer, J., Ernst, M., and Sieghart, W. (2006). Identification of amino acid residues important for assembly of GABA receptor alphal and gamma2 subunits. J. Neurochem. 96, 983-995.

Sarto-Jackson, I., Milenkovic, I., Smalla, K. H., Gundelfinger, E. D., Kaehne, T., Herrera-Molina, R., Kiebler, M. A., Thomas, S., and Sieghart, W. (2012). The cell adhesion molecule neuroplastin-65 is a novel interaction partner of $\gamma$ Aminobutyric acid type A receptors. J. Biol. Chem. 287, 14201-14214.

Sarto-Jackson, I., and Sieghart, W. (2008). Assembly of GABA(A) receptors (Review). Mol. Membr. Biol. 25, 302-310.

Sassoè-Pognetto, M., Kirsch, J., Grünert, U., Greferath, U., Fritschy, J. M., Möhler, H., and Betz, H., and Wässle, H. (1995). Colocalization of gephyrin and GABAA-receptor subunits in the rat retina. J. Comp. Neurol. 357, 1-14.

Schrader, N., Kim, E. Y., Winking, J., Paulukat, J., Schindelin, H., and Schwarz, G. (2004). Biochemical characterization of the high affinity binding between the glycine receptor and gephyrin. J. Biol. Chem. 279, 18733-18741.

Schwarz, G., Schrader, N., Mendel, R. R., Hecht, H. J., and Schindelin, H. (2001). Crystal structures of human gephyrin and plant Cnxl G domains: comparative analysis and functional implications. J. Mol. Biol. 312, 405-418.

Schweizer, C., Balsiger, S., Bluethmann, H., Mansuy, I. M., Fritschy, J. M., Mohler, H., and Luscher, B. (2003). The gamma 2 subunit of $\mathrm{GABA}(\mathrm{A})$ receptors is required for maintenance of receptors at mature synapses. Mol. Cell. Neurosci. 24, 442-450.

Sertie, A. L., de Alencastro, G., de Paula, V. J., and Passos-Bueno, M. R. (2010). Collybistin and gephyrin are novel components of the eukaryotic translation initiation factor 3 complex. BMC Res. Notes 3, 242.

Serwanski, D. R., Miralles, C. P., Christie, S. B., Mehta, A. K., Li, X., and de Blas, A. L. (2006). Synaptic and nonsynaptic localization of GABAA receptors containing the alpha5 subunit in the rat brain. J. Comp. Neurol. 499, 458-470.

Sheng, M., and Lin, J. W. (2001). Glutamatergic Synapses: Molecular Organization. Chichester: Wiley eLS. Online Library.

Shimojima, K., Sugawara, M., Shichiji, M., Mukaida, S., Takayama, R., Imai, K., and Yamamoto, T. (2011). Loss-of-function mutation of collybistin is responsible for X-linked mental retardation associated with epilepsy. J. Hum. Genet. 56, 561-565.

Sieghart, W., Fuchs, K., Tretter, V., Ebert, V., Jechlinger, M., Hoger, H., and Adamiker, D. (1999). Structure and subunit composition of GABA(A) receptors. Neurochem. Int. 34, 379-385.

Sola, M., Kneussel, M., Heck, I. S., Betz, H., and Weissenhorn, W. (2001). Xray crystal structure of the trimeric $\mathrm{N}$-terminal domain of gephyrin. J. Biol. Chem. 276, 25294-25301.

Sola, M., Bavro, V. N., Timmins, J., Franz, T., Ricard-Blum, S., Schoehn, G., Ruigrok, R. W., Paarmann, I., Saiyed, T., O'Sullivan, G. A., Schmitt, B., Betz, H., and Weissenhorn, W. (2004). Structural basis of dynamic glycine receptor clustering by gephyrin. $E M B O \mathrm{~J} .23$, 2510-2519.

Specht, C. G., Grunewald, N., Pascual, O., Rostgaard, N., Schwarz, G., and Triller, A. (2011). Regulation of glycine receptor diffusion properties and gephyrin interactions by protein kinase C. EMBO J. 30, 3842-3853.

Stallmeyer, B., Schwarz, G., Schulze, J., Nerlich, A., Reiss, J., Kirsch, J., and Mendel, R. R. (1999). The neurotransmitter receptor-anchoring protein gephyrin reconstitutes molybdenum cofactor biosynthesis in bacteria, plants, and mammalian cells. Proc. Natl. Acad. Sci. U.S.A. 96, 1333-1338.

Sudhof, T. C. (2008). Neuroligins and neurexins link synaptic function to cognitive disease. Nature 455, 903-911.

Taylor, P. M., Connolly, C. N., Kittler, J. T., Gorrie, G. H., Hosie, A., Smart, T. G., and Moss, S. J. (2000). Identification of residues within GABA(A) receptor alpha subunits that mediate specific assembly with receptor beta subunits. J. Neurosci. 20, 1297-1306.

Taylor, P. M., Thomas, P., Gorrie, G. H., Connolly, C. N., Smart, T. G., and Moss, S. J. (1999). Identification of amino acid residues within GABA(A) receptor beta subunits that mediate both homomeric and heteromeric receptor expression. J. Neurosci. 19, 6360-6371.

Tretter, V., and Moss, S. J. (2008). GABA(A) receptor dynamics and constructing GABAergic synapses. Front. Mol. Neurosci. 1:7. doi: 10.3389/neuro.02.007.2008

Tretter, V., Jacob, T. C., Mukherjee, J., Fritschy, J. M., Pangalos, M. N., and Moss, S. J. (2008). The clustering of $\operatorname{GABA}(\mathrm{A})$ receptor subtypes at inhibitory synapses is facilitated via the direct binding of receptor alpha 
2 subunits to gephyrin. J. Neurosci. 28, 1356-1365.

Tretter, V., Kerschner, B., Milenkovic, I., Ramsden, S. L., Ramerstorfer, J., Saiepour, L., Maric, H. M., Moss, S. J., Schindelin, H., Harvey, R. J., Sieghart, W., and Harvey, K. (2011). Molecular basis of the GABAA receptor $\{$ alpha\} 3 subunit interaction with gephyrin. J. Biol. Chem. 286, 37702-37711.

Triller, A., and Choquet, D. (2008). New concepts in synaptic biology derived from single-molecule imaging. Neuron 59, 359-374.

Tyagarajan, S. K., Ghosh, H., Yevenes, G. E., Nikonenko, I., Ebeling, C., Schwerdel, C., Sidler, C., Zeilhofer, H. U., Gerrits, B., Muller, D., and Fritschy, J. M. (2011). Regulation of GABAergic synapse formation and plasticity by GSK3beta-dependent phosphorylation of gephyrin. Proc. Natl. Acad. Sci. U.S.A. 108, 379-384.

Varley, Z. K., Pizzarelli, R., Antonelli, R., Stancheva, S. H., Kneussel, M.,
Cherubini, E., and Zacchi, P. (2011). Gephyrin regulates GABAergic and glutamatergic synaptic transmission in hippocampal cell cultures. J. Biol. Chem. 286, 20942-20951.

Wagoner, K. R., and Czajkowski, C. (2010). Stoichiometry of expressed alpha(4)beta(2)delta gammaaminobutyric acid type A receptors depends on the ratio of subunit cDNA transfected. J. Biol. Chem. 285, 14187-14194.

Wang, H., Bedford, F. K., Brandon, N. J., Moss, S. J., and Olsen, R. W. (1999). GABA(A)-receptorassociated protein links GABA(A) receptors and the cytoskeleton. Nature 397, 69-72.

Wenner, P. (2011). Mechanisms of GABAergic homeostatic plasticity. Neural Plast. 2011, 489470.

Xiang, S., Nichols, J., Rajagopalan, K. V., and Schindelin, H. (2001). The crystal structure of Escherichia coli MoeA and its relationship to the multifunctional protein gephyrin. Structure 9, 299-310.
Yang, T., Zhou, D., and Stefan, H. (2010). Why mesial temporal lobe epilepsy with hippocampal sclerosis is progressive: uncontrolled inflammation drives disease progression? J. Neurol. Sci. 296, 1-6.

Yu, W., Jiang, M., Miralles, C. P., Li, R. W., Chen, G., and de Blas, A. L. (2007). Gephyrin clustering is required for the stability of GABAergic synapses. Mol. Cell. Neurosci. 36, 484-500.

Zhang, C., Atasoy, D., Arac, D., Yang, X., Fucillo, M. V., Robison, A. J. Ko, J., Brunger, A. T., and Sudhof, T. C. (2010). Neurexins physically and functionally interact with GABA(A) receptors. Neuron 66, 403-416.

Zita, M. M., Marchionni, I., Bottos, E., Righi, M., Del Sal, G., Cherubini, E., and Zacchi, P. (2007). Postphosphorylation prolyl isomerisation of gephyrin represents a mechanism to modulate glycine receptors function. $E M B O$ J. 26 , 1761-1771.
Conflict of Interest Statement: The authors declare that the research was conducted in the absence of any commercial or financial relationships that could be construed as a potential conflict of interest.

Received: 04 December 2011; accepted: 23 April 2012; published online: 15 May 2012.

Citation: Tretter V, Mukherjee J, Maric $H-M$, Schindelin $H$, Sieghart $W$ and Moss SJ (2012) Gephyrin, the enigmatic organizer at GABAergic synapses. Front. Cell. Neurosci. 6:23. doi: 10.3389/fncel. 2012.00023

Copyright (c) 2012 Tretter, Mukherjee, Maric, Schindelin, Sieghart and Moss. This is an open-access article distributed under the terms of the Creative Commons Attribution Non Commercial License, which permits non-commercial use, distribution, and reproduction in other forums, provided the original authors and source are credited. 